\title{
A ORIGEM DO BIODIREITO UNIVERSAL. Morte relativa: um Direito Artificial, uma nova sistemática interpretativa para o Direito ${ }^{1 / 2}$
}

\author{
THE ORIGIN OF UNIVERSAL BIOLAW. RELATIVE DEATH : an Artificial Right, a new legal \\ interpretation system
}

Newton Martins Pina ${ }^{3}$

\begin{abstract}
Resumo:
O presente trabalho, direcionado ao Biodireito, visa apresentar uma nova modalidade de ficção jurídica, a "morte relativa", inerente à "relação jurídica de Direito Artificial", ambas vinculadas ao surgimento do novo Direito - "Direito Artificial", que ampara, além da pessoa humana, outras espécies de vidas humanas: o indivíduo humano e os "fragmentos humanos", estes possuidores de "capacidade mediata imprópria" de direitos e deveres. O tema, em questão, transcende aos conceitos conhecidos de morte, vida e dignidade, cuja Medicina, ao artificializar o Direito Natural inato, fornece à Humanidade o "atributo artificial", amparado por "sentimentos bilaterais análogos", efetivando-se um "sistema contratual-altruístico" com força de coisa julgada. Há algum tempo caminha-se numa nova era - o "período cíclico", em que há necessidade, urgente, de se quebrar paradigmas, cuja "consciência" é o verdadeiro valor ser humano. Hoje se convive com a "responsabilidade jurídicobiológica ilimitada", cujo Direito, por falta de amparo legal, diante da evolução da Medicina, tem enormes probabilidades de praticar a injustiça, a insegurança e a indignidade. Esse estudo é o avanço para a desbiologização do Direito. É a origem do novo princípio constitucional, o "Princípio da Dignidade da Vida Humana".

Palavras-chave: Biodireito. Morte Relativa. Direito Artificial. Relação Jurídica de Direito Artificial. Período Cíclico. Atributo Artificial. Sentimentos Bilaterais Análogos. Sistema Contratual-altruístico. Dignidade da Vida Humana. Fragmentos Humanos. Responsabilidade jurídicobiológica Ilimitada.
\end{abstract}

\begin{abstract}
:
The present paper, directed towards Biolaw, aims at presenting a new modality of legal fiction, "relative death", inherent to the "artificial rights jural relation", both linked to the advent of the new right -"artificial right", which protects human beings and other kinds of human life: human individuals and "human fragments"; the latter possessing "improper mediate capacity", of rights and obligations. The theme called into question transcends the already known concepts of death, life and dignity, the Medicine of which, upon making the innate natural rights artificial, provides humanity with the "artificial attribute", supported by "analogous bilateral feelings",
\end{abstract}

1 O Autor dedica esse artigo à Humanidade, pois ela é a destinatária final do objeto desse estudo.

2 São devidos agradecimentos à Revista da Faculdade de Direito da Universidade de São Paulo, pelo respeito, profissionalismo, coragem e determinação; ao transmitir esperanças jurídicas à Humanidade.

3 Newton Martins Pina, bacharel em Ciências Jurídicas e Sociais - Direito, pela Faculdade de Direito de Bauru - Instituição Toledo de Ensino - ITE. E-mail: newpina@ig.com.br. O Autor é convidado especial nesta edição da Revista, sendo o trabalho redatorial indicado pela Professora Associada do Departamento de Direito Civil, desta Academia de Direito, Giselda Maria Fernandes Novaes Hironaka, e aprovado pela Comissão de Publicação, em outubro de 2007. 
thus putting into effect a "contractual-altruistic system" with powers of res judicata. For some time now, the world has been stepping into a new era - the "cyclical period", in which there is an urgent need for breaking paradigms, the "conscience" of which is the true value of the human being. Presently, one is on intimate terms with the "limitless biolegal responsibility", the Law of which, due to the lack of legal protection in view of the evolution of Medicine, has a huge probability of giving rise to insecurity, injustice and indignity when practiced. The present paper represents advancement towards the "debiolization" of the Law. It is the origin of the new constitutional principle, the "Principle of the Dignity of Human Life".

Keywords: Biolaw. Relative Death. Artificial Rights. Artificial Right Jural Relation. Cyclical Period. Artificial Attribute. Analogous Bilateral Feelings. Contractual-altruistic System. Dignity of Human Life. Human Fragments. Limitless biolegal responsibility.

[...] "delicadíssimo fixar o instante físico do início e do fim $d a$ vida. $O$ Direito não trabalha somente com batimentos do coração ou de outro sintoma de organismo vivo. A vida $e ́$, antes de tudo, presença do valor ser humano.[...]. Valor, no sentido de significado, de representação de idéia, ou de objeto a ser preservado".

(Luiz Vicente Cernicchiaro)

"A vida é complexamente simples para ser vivida, e simplesmente complexa para ser entendida".

"A Consciência é a arte; a Biologia, o meio de expressão; $e$ o Direito, o amparo da dignidade".

(Newton Martins Pina)

\section{Questões Preliminares}

Este artigo possui conteúdo atualizado em relação ao trabalho monográfico de conclusão do curso de Ciências Jurídicas e Sociais - Direito, em 2005, cujos direitos autorais nos foram reservados.

Houve necessidade de sucessivas repetições dos conceitos propostos, com o propósito de auxiliar o entendimento desse estudo.

A proposta desse estudo é ambiciosa e, absolutamente, favorável à vida, em toda a sua amplitude, e as citações de alguns exemplos, cujos reflexos, que aparentemente possam apresentar-se negativamente, diante da visão média da crítica social, não traduzem os seus verdadeiros sentimentos, nem tampouco o do Autor, pois são apenas situações para esclarecer e alertar a sociedade quanto à urgência de se criar lei específica, ou modificar 
as existentes, que entendemos não possuírem amparo constitucional diante das novas exigências sociais.

Seu objetivo é o de pensar juridicamente, com o intuito de auxiliar o nosso ordenamento jurídico e, conseqüentemente, à Humanidade, sobre as diversas lacunas existentes e as que serão abertas no futuro próximo, decorrentes do avanço acelerado das pesquisas científicas que envolvam vidas humanas; cuja Medicina, tratada nesse estudo como gênero, ao trazer soluções inéditas à demanda social, interfere, ao mesmo tempo, na sucessão lógica do futuro da história humana, modificando-a.

Embora esse estudo, inicialmente, tenha sido direcionado ao Direito Civil, ramo do Direito Privado, está intimamente ligado ao novo ramo - o Biodireito. E não podemos deixar de observar os relevantes reflexos nos demais ramos do Direito, cuja proposta é a demonstração do surgimento da nova relação jurídica - "relação jurídica de Direito Artificial", criada pela união da "morte relativa" e do "Direito Artificial", em que dá origem à nova sistemática de raciocínio interpretativo para o Direito, ao amparar, com responsabilidade, situações atípicas inseridas na sociedade, outrora utópicas.

Contudo não tivemos, em quaisquer circunstâncias, pretensão, com o estudo inicial, de se criarem dogmas ou criticar, destrutivamente, as convicções científicas, religiosas, morais ou éticas; ou quaisquer outros ramos que auxiliam a existência e a preservação da vida humana.

2. A necessidade de uma nova sistemática para o Direito

Às vezes, nos deparamos com pensamentos que transmitem intensa inquietude interior, como que contrariassem a nossa própria existência - é a consciência da infelicidade.

A busca por respostas desejadas transforma-se numa obsessiva procura por soluções, muitas vezes, distantes da compreensão padrão e acomodada do raciocínio humano.

Encontrar essas respostas é sentir-se envolvido numa relação íntima com a genialidade, definida pelo dualismo paradoxal: bem e mal; que se encontra adormecida em todo o ser humano consciente, ou-não.

Para despertá-la, faz-se necessário um encontro íntimo de quatro elementos: o ser, a aptidão individual, o impulso motivador e a disciplina. 
Importante observar que a pessoa humana, ao despertar a sua genialidade, revela-se num paradoxo da própria espécie: é o "milagre humano", um êxtase existencial.

Infelizmente, nos dias atuais, são raras as pessoas que têm a possibilidade de se despertar, pois lutam, desesperadamente, sem rumo, contrariando a própria natureza, apenas para armazenar "alimentos", que suavizam, equivocadamente, as necessidades do "corpo".

A máxima da genialidade humana, sem qualquer dúvida, advém da união do espermatozóide (célula sexual masculina) ao óvulo (célula sexual feminina), em que dá origem à concepção de uma nova vida humana. Uma "máquina" tão perfeita, cuja expressão máxima da sua perfeição - a pessoa humana -, jamais conseguirá copiá-la, utilizando-se de materiais e métodos artificiais; no máximo solucionar, artificialmente, alguns acidentes biológicos; que também não deixariam de ser genialidades.

Não podemos afirmar qual a verdadeira razão para que essa inquietude se transforme numa obsessiva procura por respostas produtivas, mas pode-se afirmar que tal conduta, aliada à "essência da vida humana", sempre possui o poder de transformar a própria vida; no sentido de se resgatar, beneficamente, os seus verdadeiros valores.

Nesse sentido, a genialidade não se define por uma, obra grandiosa que se exaure pelo acúmulo de riquezas materiais, que pode até acontecer, mas pela simples grandeza do estado de espírito em perfeita harmonia com a natureza - é a simbiose pura da vida.

Contudo, devemos ter muito cuidado, pois os obstáculos impostos pela vida induzem-na, quase sempre, à sua falsa percepção, que aos poucos a escondem, tendenciosamente ao esquecimento.

A indagação sobre o significado da expressão "essência da vida", revelarnos-á respostas variadas, que enfocam valores morais, éticos, materiais, religiosos ou, simplesmente, conclusões simplistas da filosofia popular como as expressões: "é o levar a vida" ou "é o viver".

Essa variação de respostas, quase sempre, é a fuga que a ignorância ou a comodidade humana, até mesmo inconsciente, procura dar às soluções ao próprio egoísmo; pois não se tratam de respostas conclusivas, apenas exteriorizações de convicções de vida, na maioria das vezes, equivocadas.

No sentido social e jurídico é obrigatório que haja consenso sobre o significado da expressão "essência da vida". 
Não há de se procurar argumentos para explicar a essência da vida humana, apenas o dever de entendê-la e senti-la, segundo uma simples reflexão: "quando conseguires enxergar o sofrimento alheio e entendê-lo como se fosse o seu, eis a 'essência da vida".

As respostas estão vinculadas aos atos de solidariedade, e as convicções individuais devem ser reeducadas e direcionadas, como meio instrumental, para a realização desses atos, que, se disciplinados conscientemente, transformam-se em aprendizado da nova linguagem vital.

A Medicina - Ciência da Vida -, foi a primeira a interpretar essa linguagem, entender o sofrimento alheio e transformá-lo em expectativa de vida e dignidade, ao fornecer à Humanidade o atributo artificial, que passa a integrar-se ao campo da dignidade da vida humana.

Não é mais possível analisar separadamente a vida, a morte e a dignidade, diante das novas relações de vida, que se apresentam inéditas e crescentes no mundo jurídico-social.

São essas novas relações que afloraram a inquietude pela procura de respostas à seguinte indagação: "como podemos considerar absolutamente morto um ser humano que, mesmo depois de morto, possui capacidade de alterar o mundo dos fatos, juridicamente relevantes, no futuro?"

Essa indagação desencadeou nossa luta para se criar esse estudo inicial, cujo sistema dedutivo, puramente científico, não nos deu subsídios suficientes para se demonstrar, claramente, o caminho mais reto a ser seguido; mas nos deu o privilégio do primeiro passo, e o sentimento do dever iniciado, como meta do objetivo a ser alcançado.

Uma luta árdua que, aparentemente, contraria a própria ordem jurídica instituída, ao se demonstrar uma nova referência de interpretação jurídica; que, unindo-se à existente, a auxilia na capacidade de amparar uma dignidade mais ampla - a dignidade da vida humana.

Assim concretizou-se o primeiro trabalho - monografia (2005), intitulada Morte Relativa: Um Direito Artificial, que deu origem a esse estudo, e que nasceu rotulado pelo surgimento do "Direito Artificial", e pela responsabilidade de apresentar ao mundo jurídico o ramo autônomo do Biodireito Puro, visto como uma nova estrutura jurídica em prol da vida, embasada pela nova relação jurídica de Direito Artificial.

Pode parecer contraditório que essas novas relações de vida, embora atípicas, chamamo-nas de jurídicas. Isso acontece porque são atípicas quanto à sua formação estrutural, e jurídicas, quanto aos seus efeitos sociais. 
Entendemos que a expressão Biodireito, embora muito discutida por autores jurídicos, é, até hoje, utilizada equivocadamente, pois tudo que se discute pende para os princípios éticos, morais, religiosos, etc., segundo a conveniência interpretativa de cada instituição envolvida.

O Biodireito Universal, entendido como ramo autônomo, apresentado por esse estudo, além de absorver o Direito Ambiental, os Direitos Humanos e a Bioética, é a única disciplina que se relaciona, diante da Constituição Federal, numa posição de hierarquia, pois se embasa sobre "princípios universais e supremos" que cingem a vida planetária (Direito Universal). Esse novo Direito traz uma estrutura moderna que delimita a área de atuação de cada uma das instituições envolvidas, ao oferecer a dinâmica do mundo do querer-ser, cuja autonomia do consciente individual acompanha a evolução da Medicina, segundo o estudo empírico das possibilidades apresentadas, ou seja: a evolução da Medicina apresenta novas possibilidades de preservação ao ser humano, com o oferecimento de novos "atributos artificiais".

Quando se debatem, por exemplo, o início e o fim da vida humana, vistos não pelos propósitos e finalidades da sua essência e materialidade, vinculadas à Teleologia - ciência dependente de qualquer outra, desde que guie a natureza e a Humanidade, ao definir metas, objetivos ou finalidades últimas; discutem-se princípios éticos, morais, ou religiosos da sociedade, vinculados à Bioética, segundo interesses diversos, muitas vezes alheios ao próprio interesse da "essência da vida".

Nesse sentido entende-se não ser o Direito competente para dar o veredicto sobre o seu início ou fim. Ao Direito compete, apenas, disciplinar o comportamento humano, segundo a Deontologia jurídico-social, que, analogicamente, pode-se vislumbrála, ao disciplinar um dever-fazer à sociedade, vinculado à interpretação teleológica que a Medicina dá à materialidade biológica humana em determinado período da evolução social.

Como conseqüência, compete à Medicina decidir sobre o seu início ou fim, segundo a sua interpretação teleológica sobre a materialidade humana; cuja Deontologia médica, analogicamente vislumbrada no momento em que ela oferece à sociedade novos "atributos artificiais", com finalidade diversa das conhecidas; introduz na sociedade um novo caminho para o que se deve e o que se pode fazer.

Esse é um dos motivos de grande preocupação, que se foi revelando com o aprofundamento dos estudos no campo da Bioética, pois existe uma "guerra" que se trava quanto às discussões sobre o início e o fim da vida, e quanto ao verdadeiro bem jurídico a ser tutelado, ou seja: a Biologia, a consciência ou ambos. 
Essa preocupação é extremamente relevante, mas entendemos carecer de embasamento jurídico sólido, ou seja, um estudo em que se demonstrem às contradições, as lacunas e as omissões da ordem jurídica instituída, apresentando-se soluções sob a ótica de uma visão atualizada de interpretação jurídica, que acompanhe a atualidade do amparo à vida humana com abrangência mais ampla, segundo a evolução da Ciência - campo do Biodireito.

Mesmo porque não se chegará a consenso, pois todas as instituições envolvidas sejam sociais, religiosas, científicas, etc., encontram-se, absolutamente, confusas e invadem-se mutuamente, pois não interpretam uma mesma "linguagem vital". Nem, ao menos, cogitam a possibilidade do início da vida humana anteceder a toda essa discussão, pois não se deve esquecer que a concepção é fruto da antecedência de dois seres humanos sem consciência, ou duas vidas humanas, ou "fragmentos humanos" - o óvulo e o espermatozóide, em perfeita harmonia com o impulso biológico da procriação humana.

Aceitar essa linha de raciocínio é assumir a discussão de quem nasceu primeiro, o homem ou o fragmento humano. Discussão que não se chegaria a qualquer conclusão, apenas iniciaria uma nova "guerra" entre as instituições ligadas à vida humana.

Não é competência do Direito entender o sentido da vida humana, segundo a sua materialidade. Compete-lhe, apenas, a criação de um sistema de disciplina humanolegal, com amparo, incondicional, da Medicina; cuja finalidade é a de intermediar e solucionar os conflitos, segundo sábia interpretação dos propósitos da sua essência.

"A vida é complexamente simples para ser vivida, e simplesmente complexa para ser entendida".

A frase acima compõe-se, propositadamente, de duas partes: a primeira vincula-se ao Direito, pois possui o dever de disciplinar a complexa simplicidade da vivência, segundo os propósitos da sua essência; e a segunda vincula-se à Medicina, que tem como objetivo entender a complexidade da sua materialidade.

Por isso tornou-se necessária à criação de novas frases, novos conceitos e novas terminologias jurídicas, segundo essa nova "sistemática de interpretação jurídica".

Nova sistemática no sentido de se resgatar o único princípio admissível diante da universalidade vital, o "Princípio da Supremacia Vital", que, diante das novas relações de vida, resgata a subordinação de todos os outros subprincípios como: " $d a$ Essência Vital", "da Linguagem Vital", "do Equilíbrio Vital”, "da Reciprocidade Vital”, "do Equilíbrio Vital", "da Horizontalidade Hierárquica da Efetividade Vital", "da Autonomia do Consciente" e "da Dignidade da Vida Humana". 
2.1. Princípios inerentes à nova sistemática proposta

Faz-se necessário, diante das novas relações de vida, entendermos a extrema necessidade de se ampliar a visão principiológica do ordenamento jurídico atual, com o intuito de prepará-lo diante das inevitáveis mudanças.

Princípios relacionados à visão humana do ser, segundo a sua essência, e que transcende à livre manifestação do pensamento, contida no art. $5^{\circ}$, IV, do texto constitucional; que alguns autores rotulam-na de "direito de opinião", ou ao próprio direito de expressão, contido no art. $5^{\circ}$, IX, do mesmo texto; que, de qualquer forma, dá o direito à livre expressão do arbítrio individualista, uma espécie de poder discricionário.

Um vincula-se a juízos de valor, em que a pessoa, muitas vezes, se prevalece da conveniência de interesses pessoais para expressar uma opinião; o outro tão-somente vinculado à exaltação da expressão, no sentido individualista, que pode se manifestar com pluralidade de formas, como as artes em geral.

Esses novos princípios não expressam o egocentrismo interesseiro ou criativo, pois estão vinculados à generalidade de atitudes inerentes à essência do ser, que se encontram, na grande maioria das pessoas, reprimidas.

Esses novos princípios carregam o compromisso do despertar humano, do reaprender com o dever de compromisso com a vida, do desprendimento materialbiológico, cuja manifestação vincula-se à essência intrínseca do ser - o poder-dever da libertação do consciente justo-digno-altruísta; ao trazer para si a proteção do ato jurídico perfeito e da coisa julgada, não-só no sentido jurídico, mas no sentido hierárquico da supremacia vital.

Nesse sentido, faz-se necessária a criação de alguns princípios decorrentes dessa "Nova Estrutura de Vida" - Neolebensverhãltnis; se é que podemos chamá-la assim.

A seguir, breves considerações sobre os princípios propostos.

\subsection{1. "Princípio da Supremacia Vital"}

Existem coisas que são inquestionáveis, dignas de extrema admiração, que simplesmente nos cingem e nos reduzem à posição de inferioridade, diante de uma grandeza reverenciada.

A vida é um contexto de presença em todos os instantes, onde tudo acontece, e que transcende à capacidade de percepção do raciocínio humano. 
Esse princípio possui a mais ampla acepção, pois abrange, além da vida humana, todas as espécies de vidas conhecidas, as que imaginamos conhecer e as que jamais conheceremos.

Ele detém a "linguagem universal" - a "linguagem vital" -, que já é interpretada e respeitada por todas as espécies de vida existentes no Universo, independentemente de espécie, planeta, galáxia, etc.

Infelizmente, ela carrega o fardo de suportar a ofensa de uma única espécie - a pessoa humana -, que se intitula, suposta e arrogantemente, racional.

Dele decorrem outros subprincípios mais adequados a cada segmento dessa nova estrutura de vida; que se seguem, abaixo, num posicionamento descendente da correlação hierarquia-subordinação.

\subsection{2. "Princípio da Essência Vital"}

Como dito anteriormente, não há de se procurar argumentos para se explicar a "essência da vida humana", apenas o dever de entendê-la e senti-la, segundo uma simples reflexão: "quando conseguires enxergar o sofrimento alheio e entendê-lo como se fosse o seu, eis a 'essência da vida".

É o "princípio do sentimento" intrínseco de qualquer ser, que se revela numa simbiose harmônica de atitudes guiadas pelo impulso biológico, ou pelo consciente justo-digno-altruísta.

Por mais contraditório que possa parecer, a "essência da vida" já é conhecida, respeitada e aplicada por todos os seres considerados irracionais.

"Esse é o momento em que devemos refletir que a 'racionalidade humana' é apenas uma questão de ponto de vista".

É absolutamente desastroso, como já acontece pela diversidade de exemplos, seguir-se sem o entendimento de expressões como: justiça, dignidade, solidariedade, altruísmo, respeito, preservação auto-sustentável, meio ambiente, paz, harmonia, trabalho, etc.

O período cíclico, indicado nesse estudo, mostra-nos o único caminho para a conscientização da Humanidade; que deve admitir os erros e a necessidade de interpretar a verdadeira linguagem vital.

É o momento de admitir a busca pelo essencial, com a prática da "revolução dos valores", para que possamos interromper o processo de "estelionato institucionalizado", que se enraíza na sociedade, na ordem mundial. 


\subsection{3. "Princípio da Linguagem Vital"}

A "linguagem vital" é universal, pois se encontra presente em toda a diversidade de vida, sejam animais, vegetais, minerais, etc.

Ela possui o "impulso biológico" como meio de manifestação. Como exemplo: a "corrida" dos espermatozóides, em direção ao óvulo, com a finalidade predeterminada de fusão-concepção, demonstra-nos uma espécie de "Teleologia Biológica".

Restringindo-se essa linguagem ao campo jurídico, tem-se um Princípio que visa disciplinar o respeito e os limites de atuação entre as instituições envolvidas à vida humana.

Trata-se de linguagem extremamente complexa, não sendo possível decifrála numa só Ciência; devendo-se considerar as peculiaridades das "ciências simbióticas": Ontologia - ciência ou tratado do ser, independentemente do modo como se manifesta; Deontologia - ciência ou tratado dos deveres; Teleologia - ciência que explica os seres pelo fim a que, aparentemente, são destinados; Epistemologia - ciência que estuda o grau de certeza do conhecimento científico; a Axiologia - ciência que estuda os valores; etc.

A Medicina, no sentido específico, ao estudar o ser humano, segundo a generalidade da sua natureza plena, possui característica ontológica. Deve entendê-lo e identificar uma finalidade à "linguagem vital", segundo interpretação teleológica do seu campo de atuação, ou seja: a Medicina deve esclarecer à sociedade quais as possíveis finalidades para um determinado "ser humano", vinculando-se ao seu campo de atuação. Como exemplo, hoje se apresentam ao embrião duas finalidades últimas: transformar-se em pessoa humana, ou recuperar uma vida humana.

Já o Direito, em sentido específico, possui característica deontológica, ao disciplinar um comportamento ativo, ou omissivo, para a sociedade.

Ele deve entender a "linguagem vital", segundo a interpretação teleológica do seu campo de atuação, observando as finalidades apresentadas pela Medicina; ou seja: o Direito, ao normatizar uma disciplina social, segundo um dever-fazer, deve instituir uma disciplina social vinculada às finalidades apresentadas pela Medicina.

Na legislação atual, ao se falar de embriões - "fragmentos humanos" - é importante observar que, segundo a concepção naturalista, a Teleologia admite a procriação como última finalidade; mas, segundo a visão artificialista desse estudo, ela pode admitir, para esse mesmo embrião, a "preservação humana" como última finalidade. 
É nesse sentido que a pessoa humana, via "sistema contratual altruístico", direcionará uma finalidade à própria integridade biologica, cabendo ao Direito, apenas, criar condições para a sua efetivação.

Somente com respeito recíproco a Medicina e o Direito evoluirão com plena liberdade de expressão, e amparar-se-ão pela dinâmica do comportamento social, sem mútua interferência.

\subsection{4. "Princípio do Equilíbrio Vital"}

O estudo científico apresenta a gênese do planeta Terra como pretéria à do ser humano, e que se distanciam por bilhões de anos. Tempo suficiente para estruturar uma biodiversidade de produção regenerativa, constituída de "cadeia alimentar" autosustentável.

Nesse período, todas as espécies de vida possuíam uma capacidade suprema de interagir, "racionalizar" e interpretar uma "linguagem universal" (a "linguagem vital") materializada pelo "impulso biológico" dotado de "percepção vital", cujo propósito é o "equilíbrio do processo vital".

Num determinado momento, inseriu-se, nessa "estrutura ecossistêmica", o ser humano. Ele deveria assumir uma posição de subordinação e reverência, diante das vidas preexistentes, pois, tornou-se o membro mais frágil; considerando-se a sua particularidade de consumidor-extrativista.

Contudo, não podemos negar que a pessoa humana possui algo diferenciador, ou seja, uma energia que alimenta o próprio corpo, e que a torna capaz de uma criatividade, "inesgotável", vinculada ao poder de "transformação" do meio.

O tempo passa, e a pessoa humana continua amparando-se pela falsa percepção de dignidade, pois, reiteradamente, desrespeita todo esse complexo biodiverso, e a si mesma, ao ignorar o seu grau de dependência, assumindo uma posição de "ditadora universal".

Entretanto, o processo vital baseia-se num sistema dualista, que o entendemos como bases de equilíbrio vital, como exemplos: corpo e alma, vida e morte, amor e ódio, calor e frio, luz e escuridão, direito e dever, positivo e negativo, bem e mal, ação e reação, etc.

Não sabemos o motivo da racionalidade humana não ter conseguido interpretaressa "linguagem vital", conseqüentemente, o seu "corpo"e "alma" desequilibramse, no momento em que a pessoa humana permitiu que a sua "racionalidade" ultrapassasse 
os limites do próprio corpo, em nome de uma ambição caracterizada pelo "egoísmo egocêntrico da alma". Iniciou-se o processo de decadência do Império Humano.

Resta-nos pouco tempo para entendermos que a pessoa humana se constitui de duas formas de vidas: biológica, cuja sobrevivência depende dos mesmos elementos existentes no meio ambiente; e a imaterial, ou seja, uma alma, um espírito, uma consciência ou uma energia que alimenta àquela. Ambas deveriam viver em equilíbrio, com o único propósito de interpretar a "linguagem vital", mantendo, assim, o processo do "equilíbrio vital".

Contudo, deveríamos ter a sensibilidade em observar que essa linguagem é sutil, sensível, e educada, pois, não-reclama, impulsivamente, aos impactos desrespeitosos impostos pelo homem, tenta absorvê-los em silêncio, sejam desmatamentos, poluição dos rios e do ar, matança indiscriminada de animais, etc.

O seu silêncio é eloqüente, contudo, deveríamos saber que as suas respostas viriam com o limite da sua capacidade de sustentação, manisfestadas com exemplos de devastação da vida humana, pois, o limite do desrespeito ativo é a devastação como resposta reativa ("Princípio do Equilíbrio Vital”).

Diante do exposto, qualquer interferência humana que tende ao desequilíbrio ecossistêmico, e conseqüente extinção da biodiversidade, tratar-se-á de crime contra a Humanidade, um genocídio iminente, não um crime ambiental. Pois, o que se ataca, de fato, é a cadeia alimentar, fonte elementar de sobrevivência da espécie humana.

\subsection{5. "Princípio da Reciprocidade Vital"}

Precisamos entender que o atributo, "vida humana", não pertence a um organismo biológico que se intitula "racional". Ela pertence a uma "estrutura ecossistêmica", na qual foi inserida como membro mais frágil, pois depende desta, como fonte alimentar, para suprir a sua própria existência.

Esse é o ponto inicial para entendermos que qualquer ataque nocivo a essa estrutura ecossistêmica, não se trata de mero crime ambiental, e que deverá ser entendido como crime contra a Humanidade - um crime de genocídio iminente.

Em outro sentido, a reciprocidade vital vincula direitos e deveres, que entendemos ser uma correlação intrínseca ao processo vital.

A partir do momento em que a sociedade aceitou a artificialização do processo natural - "atributo artificial", como um "direito legítimo" - aceitou-o, também, 
como um “dever legítimo". Contudo, sabemos que a sociedade não tem consciência desta última condição.

Nesse sentido, o compromisso com a vida transcendeu às convicções do livre arbítrio individualista; pois esses direitos-deveres, específicos dessa nova era de relações jurídicas, simplesmente incorporaram-se ao "processo vital" em favor da vida humana.

\subsection{6. "Princípio Hierárquico Horizontal da Efetividade Vital"}

Restringindo-se o gênero Vida ao Planeta Terra, todas as suas espécies, quais sejam, animais, vegetais, minerais, etc, igualam-se, na horizontalidade, em grau de equivalência vital, ou seja, todos as espécies de vidas caminham lado a lado e possuem a mesma importância vital.

Considerando-se o campo da Vida Humana, aplica-se essa mesma situação, ou seja, a pessoa humana, o indivíduo humano e os "fragmentos humanos" também possuem a mesma importância Vital.

Nesse sentido, todos os seres humanos possuem o direito-dever da autopreservação biológica.

Contudo, diante de um conflito de bens humanos, esse direito-dever transcenderá ao próprio direito de sobrevivência de um, em favor de outro, cuja ordem de aproximação à pessoa humana definirá qual ser humano prevalecerá em detrimento do outro.

Não se trata da destruição de uma vida humana, mas de uma contribuição necessária à própria preservação.

Se a própria sociedade chegou à conclusão de que há necessidade de se manter um meio ambiente auto-sustentável, cuja Vida Humana foi inserida nessa estrutura biodiversa, ela tem o compromisso do "dever inato" de se auto-sustentar.

\subsection{7. "Princípio da Autonomia do Consciente"}

Desvincula o ato consciente da materialidade biológica, ao amparar-se no imperativo do consciente justo-digno-altruísta, nova modalidade contratual - sistema contratual altruístico -, criada nesse estudo, ao oferecer um destino para a materialidade biológica, segundo interesse da consciência bilateral, ou unilateral, que, por si só, é ato jurídico perfeito dotado de segurança jurídica - a coisa julgada. 
Nesse sentido, a sociedade assume o compromisso do dever inato para com a vida humana, que não se deve confundi-lo como ato obrigatório - decorrente da imposição social, ou ato compulsório - prevalência da força do Estado sobre o indivíduo.

Ambas as situações privam o direito ao livre arbítrio, contudo essas novas relações de vida, no mesmo instante em que reafirma o direito ao livre arbítrio, vinculao ao direcionamento vital, segundo o interesse do consciente justo-digno-altruísta, ou seja: a pessoa humana deve escolher um direcionamento à integridade biológica, segundo as opções oferecidas pela Medicina, jamais descartá-la, sob pena de responsabilizar-se pelo crime de omissão de socorro impróprio, nova modalidade de crime suscitado nesse estudo.

\subsection{8. "Princípio da Dignidade da Vida Humana"}

Ao tutelar "a Dignidade da Pessoa Humana", como um dos princípios fundamentais do Estado, o Direito equivocou-se; pois a evolução da Medicina - Ciência da Vida -, mostra-nos uma nova realidade de relações de vida, relações jurídicas de Direito Artificial, em que a morte relativa e o Direito Artificial uniram-se e transformaram-se numa nova sistemática interpretativa para o Direito, vinculada ao ramo autônomo do Biodireito.

Esse novo princípio, de caráter essencialmente jurídico, cuja mudança se propõe nesse estudo, decorre de princípios mais amplos vinculados à "supremacia vital"; aos quais deve obediência.

A Medicina apresentou à sociedade o atributo artificial, uma nova modalidade de capacidade intrínseca a qualquer ser humano vivo, em estado de morte relativa; e que possui relação com o mundo jurídico, entendido, nesse estudo, como "capacidade mediata imprópria" de direitos e deveres.

Essa nova modalidade de capacidade obriga-nos a um novo modo de racionalização e insere, ao mundo jurídico, novo campo de interpretação - o querer-ser.

A falta de legislação adequada apresenta à sociedade duas novas modalidades de responsabilidades: ilimitada, segundo a universalidade e retroativa, segundo a especificidade, as quais atribuirão ao ser responsável, biologicamente, capacidade e personalidade, adequando-as ao mundo jurídico. 
É mediata, porque a sua capacidade jurídica depende da união de dois seres humanos com o auxílio da Medicina. E imprópria, porque essa capacidade jurídica dependerá da união das capacidades biológicas individuais para se agregar ao ser humano.

Nesse sentido, essa nova concepção principiológica possui o objetivo de amparar todas as espécies de seres humanos, ou vidas humanas, capazes de alterar o mundo dos fatos, juridicamente relevantes, no futuro: a pessoa humana, o indivíduo humano e os fragmentos humanos.

Possui caráter essencialmente dinâmico, relacionado com a desbiologização do Direito; pois permite que a consciência humana, vinculada ao "sistema contratual altruístico", defina um destino final para a materialidade biológica e, ao mesmo tempo, identifique qual bem deva ser tutelado: a consciência, a biologia ou ambos.

\subsection{A nova sistemática diante das atuais relações de vida}

Com a seqüência e desenvolvimento nos estudos, no curso de Ciências Jurídicas e Sociais, chegamos à conclusão de que o Direito trata a pessoa humana como um bem maior. Nesse sentido, entende-se que ela é a única e legítima detentora da vida humana; tanto é verdade essa linha de raciocínio, que alguns autores se utilizam da seguinte expressão: "a vida é o bem mais precioso para cada pessoa e também para toda a Humanidade".

Conclusão que nos trouxe intenso desconforto interior, mesmo porque a Constituição do Brasil contemplava, e contempla até hoje, a Dignidade da Pessoa Humana como um dos seus princípios fundamentais.

Contudo, a evolução da Medicina - Ciência da Vida - mostra-nos uma nova realidade de "relações de vida", as "relações jurídicas de direito artificial", cuja pessoa humana assume o seu verdadeiro posto: uma interlocutora da linguagem vital, situada entre o ente e o ser humanos, que o desempenha com extrema irresponsabilidade vital.

Quando se fala sobre o ente, vida humana, devemos entendê-lo como algo inatingível, quanto à sua possível titularidade, pois ele não é objeto de propriedade, e sua existência está ao alcance de todos os seres humanos, indistintamente, como condição universal. 
Mas quando se fala sobre o ser, vida humana, devemos entender que a sua titularidade restringe-se ao campo da responsabilidade dos direitos-deveres de preservação do individualismo biológico, segundo o interesse da essência da vida.

Nesse sentido, como dissemos anteriormente, a Medicina mostra-nos que o Direito se equivocou ao tutelar a dignidade da pessoa humana, pois a Vida Humana assume o seu verdadeiro posto, como gênero pertencente a uma estrutura ecossistêmica, na qual foi inserida como membro mais frágil, e que detém três espécies humanas distintas: a pessoa humana, o indivíduo humano e os fragmentos humanos (órgãos, sêmen, óvulo, sangue, medula óssea, célula-tronco, córnea, tecido, etc.).

Segundo essa nova sistemática de interpretação jurídica, o avanço da Medicina está, transitoriamente, livre da disciplina legal, face ao ordenamento jurídico atual, quando presente o valor vida humana relacionada às novas relações de vida. Amparam-se, apenas, por leis próprias, como exemplo: Resolução CFM, n. 1.246, de 08 de janeiro de 1988 - Código de Ética e Medicina; Resolução do CFM, n. 1.358, de 11 de novembro de 1992 - Regulamenta normas éticas para utilização das técnicas de reprodução assistida (RA).

Estar livre não significa imunidade jurídica, apenas criaram-se lacunas jurídicas como fatos atípicos, cujo Direito encontra-se incapacitado para discipliná-las.

Está-se diante de um período de transição - o Período Cíclico, em que há necessidade, urgente, de se reverem conceitos e paradigmas, pois é a transposição de uma nova era, cuja sensibilidade humana tem o dever de captar e absorver.

Essa nova era, transitória, que se observa diante dessas novas relações de vida, em sentido jurídico, possui acepções muito mais amplas, que não deve ser entendida como pertencente ao período contemporâneo, pois se trata de um período em que a reflexão e reestruturação do comportamento humano definirão e garantirão a perpetuação da dignidade humana.

Até os dias atuais, a Ciência do Direito, como um todo, ampara-se no modelo dicotômico instituído no passado, em que as relações de vida se encaixam no mundo-doser ou no mundo do dever-ser.

Contudo, já se apresentam ou se vislumbram, relações jurídico-sociais, que viajarão ao passado com o intuito de modificar o futuro, não mais instituídas no mundo do ser (sein) - mundo dos relacionamentos, amparado por leis naturais, ao obedecer a uma lógica natural; ou do dever ser (sollen) - mundo da conveniência social, amparado por normas jurídico-sociais, ao obedecer a um padrão de imposição comportamental. 
Ao modificá-lo, apresentar-se-á ao futuro um novo futuro, não mais pertencente ao mesmo período de sucessão lógica temporal, nem mesmo visto como conseqüência natural da modernidade atual, pois possui o objetivo de resgatar no passado o verdadeiro sentido de dignidade.

Essa dicotomia, além do sentido de dupla divisão, possui o sentido de oposição, pois o sentido natural de aspiração de liberdade, inerente a toda pessoa humana - porque não a todo ser humano? -, contrapõe-se ao modelo formal instituído, a lei, que, de certa forma, cerceia a sua própria liberdade; um mal necessário para que se alcance a harmonia social.

Inegavelmente, nos dias atuais, deparamo-nos com relações de vida nãoadequadas a quaisquer desses campos, que se vinculam ao gênero vida humana e não à sua espécie - a pessoa humana; e que devem ser entendidas como pertencentes ao mundo do "querer-ser", que não se subordinam ao mundo dos relacionamentos ou das imposições; mas, tão-somente, ao Princípio da Supremacia Vital, cuja expressão do consciente justodigno-altruísta revela-se universalmente.

Nesse sentido, ao citar, respeitosamente, os ensinamentos de Miguel Reale, sobre a Teoria Tridimensional do Direito, que correlaciona o fato, o valor e a norma, devese complementá-la com as novas relações de vida, constituindo-se uma tridimensionalidade atípica.

Atípica no sentido de que os fatos não são elementos sociais disciplinados pelo Direito objetivo, mas tão-somente amparado pela força do Princípio da Reciprocidade Vital; o valor não é o elemento moral do Direito, mas um elemento constante e imutável - a vida humana, que decorre do Princípio da Essência Vital; e a norma não se relaciona ao padrão de comportamento social imposto pelo Estado, mas, tão-somente, à dinâmica do campo do "querer-ser", externada pelo consciente justo-digno-altruísta, embasada pelo Princípio da Autonomia do Consciente.

Essas relações jurídicas de direito artificial, ou novas relações de vida, devem ser introduzidas à estrutura social existente, transformando-a numa nova estrutura de vida - Neolebensverhãltnis.

Embora não-disciplinadas em Lei, são essencialmente jurídicas, considerando-se o efeito social, o interesse e a tentativa de tutela do Estado.

Nesse sentido é imperioso que a Ciência do Direito se atualize e adote, segundo essa nova estrutura de vida, o sistema triaxial, ao embasar-se sobre três eixos propulsores, ou seja: o mundo do ser, o mundo do dever-ser e o mundo do querer-ser. 
O que difere o novo período do outro, que se evidencia, claramente, nas relações jurídico-sociais, sócio-ambientais e político-econômicas é a obrigatoriedade da conscientização dos erros, ao resgatar no passado os verdadeiros valores da vida, fazendose o que é certo ao aplicá-las no presente, cujo propósito é o de reverter o futuro do futuro incerto, ou seja, transformar o futuro que hoje se revela incerto, diante da expectativa social, para um futuro com dignidade.

Nesse ponto de vista, está-se diante do período cíclico, que não se trata de mera imposição doutrinária e inconseqüente, mas de exigência obrigatória, incontestável e irrevogável, da sociedade mundial, pois é essa transição que definirá a transposição do futuro com dignidade sobre o futuro incerto.

É cíclico, em sentido jurídico, a partir do momento em que um ato, expressado pelo consciente justo-digno-altruísta, desvincula-se de qualquer responsabilidade jurídica no sentido retroativo, ou seja, segundo a legislação vigente, um ato de solidariedade biológica pode transformar-se, no futuro, em ato de responsabilidade jurídica.

É extremamente relevante que se amplie, nesse momento, o âmbito desse estudo, ao dizer que não há de se falar em dignidade da vida humana, sem considerá-la, absolutamente, dependente da preservação ambiental, pelo simples raciocínio de que não pode haver vida biológica humana sem o meio ambiente auto-sustentável; cuja recíproca não se faz verdadeira, ou seja, pode haver meio ambiente auto-sustentável, excluindo-se qualquer vestígio de vida biológica humana.

Essa colocação confirma o que foi dito anteriormente, ou seja, o ser humano foi inserido numa estrutura ecossistêmica como membro mais frágil.

Nessa linha de raciocínio a pessoa humana pratica uma inconstitucionalidade vital ao desrespeitar a supremacia vital, pois se comporta como alienígena ao destruir o meio em que vive para benefício próprio, como se pudesse abandoná-lo sem sofrer as conseqüências.

Entendemos que essa nova era tenha iniciado, concomitantemente, a cadeia evolutiva dos direitos fundamentais de quarta geração - manipulação genética, cujo marco inicial deve-se à primeira filiação via "bebê de proveta" (Inglaterra, 1978), pois pela primeira vez evidenciou-se, com muito mais clareza, o recurso do atributo artificial fornecido pela Medicina, ao quebrar o paradigma da irreversibilidade biológica, e transformá-la em esperança de reconstituição familiar-padrão. 
Segundo Montesquieu, a lei natural é "a relação necessária derivada da natureza das coisas", e que possuem caracteres particulares, destacando-se: a universalidade, a imutabilidade, a inviolabilidade e a isonomia ${ }^{4}$

Quanto à característica inviolabilidade, o Autor entende que há uma correlação íntima entre a ordem natural das coisas e a inseminação artificial, sob alegação de que o fenômeno já era possível, apenas faltavam, ao homem, conhecimentos e recursos tecnológicos.

Entendemos ser inadmissível aceitar a vinculação da inseminação artificial à ordem natural das coisas, mesmo porque ela possui acepção muito mais ampla do que uma simples concepção biológica, ou seja, envolvem-se capacidades, sentimentos e aspirações, aliados ao avanço da Medicina, cuja nomenclatura e procedimento, por si sós, já configuram sua artificialização.

Nesse sentido: "a ordem natural das coisas vincula-se ao atributo natural; cujo 'atributo artificial' resgata, artificialmente, a ordem natural das coisas".

A evolução da Medicina, diante das necessidades sociais, aliada à incapacidade das pessoas exercerem o Direito Natural inato - atributos congênitos, traz a necessidade de se reverem conceitos e convicções, ao enfocar os verdadeiros sentidos conceituais de vida, morte e dignidade.

O nosso ordenamento jurídico tornou-se desatualizado, diante da procura de soluções ocasionadas pela negativa desse direito, ao tutelar somente uma espécie de vida humana, a pessoa humana, como sujeito de capacidade, direito e dever.

De outro modo, existem pessoas que necessitam da capacidade de outras espécies de vidas humanas - "fragmentos humanos", para manter a própria efetividade vital, ou seja, necessita do atributo artificial para se manter com vida e ou dignidade.

Logicamente, está-se diante de capacidades diferenciadas, a jurídica e a biológica que, em tese, jamais se confundiriam.

Mas confundiram-se diante dessas novas relações de vida, ao criar, para a capacidade biológica, uma responsabilidade jurídico-biológica: retroativa no ponto de vista específico, e ilimitada no ponto de vista universal.

Entendemos que, a partir desses novos modelos de responsabilidades, o Direito tem o dever de se render a novas propostas jurídicas, imprescindíveis à criação e introdução de uma nova sistemática jurídica, razão desse estudo, que o faz ao introduzir

\footnotetext{
4 NADER, Paulo. Introdução ao estudo do Direito. 22. ed. Rio de Janeiro: Forense, 2002. p. 62.
} 
uma primeira nova nomenclatura no ordenamento jurídico, a morte relativa, diretamente ligada ao atributo artificial, originando-se à sistemática proposta.

Iniciando-se esse processo de sistematização, deve-se evidenciar a correlação íntima entre a morte relativa e o direito artificial, que devem ser entendidos como novos objetos para estudo científico.

Após profunda reflexão, concluímos que morte relativa não é uma situação isolada e relacionada a um organismo humano morto, mas, também, situação integrante de um organismo humano vivo, pois morte relativa é a ausência de consciência em alguma forma de vida biológica humana - ser humano, cuja potencialidade de alterar o mundo dos fatos, juridicamente relevantes no futuro, é fornecida pelo Direito Artificial, ou seja, o Direito Artificial oferece o direito de artificialização ao direito natural inato, via atributo artificial.

Após várias consultas em livros jurídicos, médicos, periódicos e artigos, foi-nos uma grande surpresa encontrar, em um artigo publicado por uma acadêmica da Universidade de Taubaté (Unitau), a classificação da morte como relativa.

Consta nesse artigo uma classificação extremamente singela, mesmo por se tratar de uma classificação médico-legal; em que se diz: "4. Morte Relativa: verifica-se a parada completa e prolongada do coração, todavia, a massagem cardíaca pode reanimá$10 " .5$

A expressão morte relativa, usada nessa nova proposta de estudo, vem ao desencontro do conceito médico, que a relaciona à parada do coração, com conseqüente reanimação e, também, ao caminho da falência dos órgãos.

Deve-se entender que essa classificação, morte relativa, é essencialmente jurídica, não-médica, e os casos relacionados pela Medicina estão intimamente ligados a espécies de vidas relativas no sentido físico-biológico, e o que devemos entender é que a morte é um estágio de diagnóstico do exaurimento da expressão da consciência, não do seu rompimento súbito por frações de segundos, ao configurar uma quase-morte, sem relevância para o Direito; nem mesmo do exaurimento gradativo de um complexo biológico.

“O padrão morte está intimamente ligado à 'consciência'; compete à Medicina, apenas, diagnosticá-la e ao Direito, legalizá-la”.

\footnotetext{
5 ALMEIDA, Sabrina Chagas; TEIXEIRA, José Sérgio Boscayano. Conceito médico-legal de morte e aspectos médico-legais. Disponível em: <http://www.neofito.com.br/artigos/art01/jurid27.htm> Acesso em: 07 mar. 2005 .
} 
Para o futuro, utopicamente falando, deve-se acreditar que a Ciência conseguirá separar a consciência do organismo biológico-humano.

Nesse sentido, o Direito deverá confirmar e aceitar a inexistência da morte absoluta, dando origem ao ramo do Direito Metafísico ou Direito Transcendental.

3. Breves considerações sobre o conceito de vida humana

Qual o sentido de vida humana para o Direito atual?

Inadequada e inoportuna qualquer discussão sobre vida humana sem o questionamento: o que é vida?

O conceito de vida é absolutamente abrangente, pois se trata de um gênero, nesse sentido, além do seu próprio conceito, fazem-se necessárias reflexões independentes sobre questionamentos de algumas de suas espécies, ou seja, o que é vida biológica?; o que é vida humana?; o que é pessoa humana?; e o que são "fragmentos humanos"?

Tais questionamentos são imprescindíveis para o entendimento da divisão tripartite, proposta nesse estudo, usada como instrumento propulsor.

Segundo Francisco da Silveira Bueno e Luiz Antonio Sacconi, vida é:

s.f. Estado de atividade funcional, peculiar aos animais e aos vegetais; existência; tempo decorrido entre o nascimento e a morte; modo de viver; animação em composições literárias ou artísticas; animação; vitalidade; subsistência. vida. ${ }^{6}$

s.f.(a) 1. Estado ou condição característica de um organismo vivo. 2. Conjunto de organismos vivos. 3. Intervalo de tempo entre o nascimento e a morte. 4. Seres vivos. 5. Vitalidade. 6. Expressividade; vigor?

Diante da necessidade de se demonstrar maior alcance, Vida é mais que isso, não abrange somente o campo dos organismos com vitalidade e expressividade, nem mesmo o intervalo de tempo entre o nascimento e a morte, mas um conjunto de sentidos que demandam a percepção humana e além dela.

Esse conjunto de sentidos compreende:

- um sentido natural - que provém da criação da natureza, como os animais racionais, ou-não, os vegetais e os minerais;

- um sentido biológico - órgãos, ou organismos, com funções metabólicas - reações químicas, amparadas pelo impulso natural da vida biológica;

\footnotetext{
6 BUENO, Francisco da Silveira. Minidicionário da língua portuguesa. São Paulo: Atual, 2000. p. 797.

7 SACCONI, Luiz Antônio. Minidicionário Sacconi da língua portuguesa. São Paulo: Atual, 1998. p. 677.
} 
- um sentido social - estabelecido por regras de comportamento, vinculadas aos costumes, à moral e à ética;

- um sentido filosófico - a pura expressão da consciência: o pensar, o raciocinar;

- um sentido jurídico - entendido como o campo do dever-ser, cuja capacidade de contrair direitos e deveres deve-se à conduta obrigatória de imposição legal - Lei;

- um sentido religioso - o caráter dogmático da crença, é a incontestável verdade de fé;

- um sentido dimensional - o que transcende ao tempo e ao espaço, além da compreensão humana;

- um sentido cosmológico - tudo faz parte de um cosmo, um universo;

- além de outros.

Todos interagindo, harmonicamente, e contribuindo para a existência dessa magnitude chamada vida.

Nesse sentido, conceituamos-na como: "vida é o gênero, é o desígnio, é a essência naquilo que se vivencia, consciente e inconscientemente; é o que transcende ao inevitável, ao desconhecido e ao incompreensivel".

Vida biológica, no entanto, é uma espécie do gênero Vida, cuja Biologia estuda, cientificamente, a vida e a estrutura de todos os seres orgânicos e inorgânicos, a saber: animais, vegetais e minerais, considerados em suas essências biológicas individuais.

Nesse sentido, o ser humano, objeto que aqui se estuda, é visto apenas como um organismo, abstraindo-se o valor consciência, ou seja, um conjunto de órgãos com funções específicas, que realizam metabolismo - reações químicas, sustentados pelo impulso da vida biológica.

É pertinente que se entenda que a expressão ser humano não se refere, somente, à pessoa humana, mas a toda espécie de vida biológica humana, ou seja, o espermatozóide, o óvulo, o sangue, o embrião, as células-tronco, etc., obviamente, integram-se ao campo da vida humana.

Restringindo-se, pertinentemente, a essa linha de estudo, tem-se a vida humana, não como espécie do gênero vida, que realmente é, mas como gênero de três espécies distintas, ou seja: uma divisão tripartite entre: a pessoa humana (organismo humano, com vida biológica, dotado de consciência, auto-expressão e autodeterminação); o indivíduo humano (organismo humano com vida biológica) e os "fragmentos humanos" 
(partes do organismo humano com vida biológica). Como exemplos o sêmen, os óvulos, os embriões, os órgãos, os tecidos, as córneas, as células-tronco, a medula óssea, etc...

Importante reiterar o esclarecimento, nesse momento, de que a pessoa humana, o indivíduo humano e os "fragmentos humanos", se inserem na condição de vida humana, como seres humanos que são.

Antes de fazermos breves considerações sobre pessoa humana, devemos esclarecer que a palavra pessoa deriva do latim - persona -, que antigamente era o nome que se dava à máscara usada pelo artista, que amplificava o som da sua voz, ao representar um personagem, demonstrando-se plena convicção da íntima ligação da palavra com a expressão da personalidade.

São Tomás de Aquino utilizava-se da palavra pessoa para indicar a essência individual humana. ${ }^{8}$

Nesse sentido, a pessoa humana é um algo a mais, é um plus agregado ao indivíduo humano, é o acréscimo da consciência, da auto-expressão e da autodeterminação, ou seja: é a personalidade da presença.

Diz-se do indivíduo humano acrescido de alma, espírito ou energia envolvente, que o torna capaz de uma relação simbiótica entre o seu interior e a sua manifestação ao mundo exterior, a que se chama, nesse estudo, de consciência.

Para Immanuel Kant o conhecimento empírico é a transposição de um campo de experiência exterior - da observação, para um campo de experiência interior - da assimilação, ou seja, conclui-se que a pessoa humana é pré-requisito para a existência da transcendentalidade, que é o distanciamento da pessoa humana em relação ao campo de experiência, cujo propósito é categorizar aquilo que foi alvo de assimilação.

Conclui-se que a pessoa humana constitui-se de um observador próprio, que tudo vê, assimila, divide em categorias e guarda em arquivo interior - na memória.

Antonio Chaves, implicitamente, distingue indivíduo humano de pessoa humana:

A vida, em suma, é algo que oscila entre um interior e um exterior, entre uma 'alma' e um 'corpo'.?

No mesmo sentido Recasens Siches, citado por Pietro de Jesús Lora Alarcón, Heloísa Helena Barbosa e Paulo Nader:

8 TOMASEVICIUS FILHO, Eduardo. Direito civil entre a vida e a morte. Revista da Faculdade de Direito da Universidade de São Paulo, São Paulo, v. 100, p. 439, jan./dez. 2005.

9 CHAVES, Antônio. Direito à vida e ao próprio corpo: intertextualidade, transexualidade, transplante. São Paulo, Revista dos Tribunais, 1994. p. 13. 
A vida é tudo o que fazemos, mas isso não seria vida se não nos déssemos conta do que fazemos. É a vida uma realidade de peculiaríssima condição, que tem o privilégio de dar-se conta de si mesma, de saber-se. Mas este saber-se não é um conhecimento intelectual, senão esse caráter de presença imediata da vida para cada qual. Sentir-se, dar-se conta, verse, é o primeiro atributo da vida. ${ }^{10}$

Hoje, estar consciente é qualidade essencial para se falar em vida, tanto no que diz respeito ao seu início, quanto ao seu fim. Martin Rhonheimer afirma que uma das estratégias utilizadas para argumentar a favor do aborto consiste em considerar como pessoa apenas o ser dotado de autoconsciência, o distinguindo assim indivíduo de pessoa. Por isso mesmo, os anencéfalos podem ter seu processo de gestação interrompido, mesmo no Brasil, já que apresentam anomalia na qual lhes faltam a abóboda craniana, estando os hemisférios cerebrais ausentes ou representados por pequenas massas que repousam na base. ${ }^{11}$

O permanente objetivo do Direito, em suas manifestações diversas, é o ser humano. As relações que define envolvem apenas os interesses e os valores necessários ao ente dotado de razão e vontade. $\mathrm{O}$ homem constitui, pois, o centro de determinações do Direito. Na acepção jurídica, pessoa é o ser, individual ou coletivo, dotado de direitos e deveres. Além de sentido jurídico, a palavra pessoa apresenta outras conotações. Na acepção biológica, significa homem e na linguagem filosófica o ser inteligente, que se orienta teleologicamente. Do ponto de vista religioso, pessoa é o ser dotado de alma. ${ }^{12}$

O importante, para essa linha de estudo, é o entendimento da existência de algo que diferencie, juridicamente, o indivíduo humano da pessoa humana.

Finalmente os "fragmentos humanos", que se fala em nome próprio, que nada tem a ver com o sentido de destruição, pois foi a terminologia perfeita encontrada para abranger a diversidade de vidas biológicas humanas, fora dos seus organismos humanos geradores, criopreservadas ou agregadas a outros organismos humanos, e que possuem capacidade mediata imprópria de direitos e deveres, cuja finalidade é a preservação da espécie humana. Como exemplos: sêmen, óvulos, embriões, córneas, tecidos, órgãos, medula óssea, células-tronco, etc.

\footnotetext{
${ }^{10}$ ALARCÓN, Pietro de Jesús Lora. Patrimônio genético humano e a sua proteção na Constituição Federal de 1988. São Paulo: Método, 2004. p. 42.

11 BARBOSA, Heloísa Helena. Novos temas de biodireito e bioética. Rio de Janeiro: Renovar, 2003. p. 126.

12 NADER, Paulo. op. cit., p. 279.
} 
Não se pode negar que o avanço da Medicina nos proporcionou essa nova realidade de relações de vida.

Se considerarmos isoladamente os "fragmentos humanos", suas capacidades são essencialmente biológicas, mas quando se unem entre si ou a outros organismos, como exemplos: sêmen e óvulo (RA), transplante de coração, inseminação heteróloga, etc.; essa capacidade imediata que lhe é própria, no sentido biológico, ou mediata no sentido jurídico, agrega-se ao terceiro criado ou beneficiado, transformando-se em capacidade jurídica imediata e própria.

Com visão pouco mais aprofundada e levando-se em conta os relevantes benefícios oferecidos à Humanidade, destaca-se, por parte da Medicina, mesmo que inconscientemente, o oferecimento do atributo artificial, ao transformar uma deficiência física ou biológica, em esperança de dignidade.

Quanto à indagação inicial sobre o sentido de vida humana, entendemos que para o Direito, a vida se apresenta vinculada ao Princípio da Dignidade da Pessoa Humana, e intimamente relacionada à personalidade e à capacidade que as pessoas possuem de exteriorizar a consciência, cujo padrão encontra-se preestabelecido na Lei n. 10.406 / 2002 - Código Civil brasileiro.

4. Breves considerações sobre o conceito de morte

Qual o sentido da morte para o Direito atual?

"Morte, a espera mais intrigante que cinge a realidade humana, pois a única certeza que se tem, é a arte de morrer".

Segundo os biólogos, há uma ligação, extremamente relevante, entre a reprodução sexuada e a morte.

Há milhões de anos, desde o surgimento dos primeiros sinais de vida, cujos seres constituíam-se de uma única célula - unicelulares, a exemplo das bactérias, eles se desenvolviam, cresciam e duplicavam os seus genes.

Após um determinado período esse ser dividia-se em duas novas células, idênticas à original, como se fossem dois "bebês", ou seja, a "célula-mãe" apenas transformava-se em duas novas células, cujo ciclo repetia-se sucessivamente.

Nesse período não havia morte decorrente do envelhecimento celular, apenas pela falta de nutrientes do meio em que viviam.

Com o aparecimento dos seres multicelulares introduziram-se à vida duas novas situações: o sexo e a morte. 
O sexo como mecanismo de fusão entre células reprodutoras de organismos distintos, como exemplo, a fusão do espermatozóide ao óvulo - concepção.

E a morte relacionada ao surgimento de novas células, cujo material não seria incorporado ao novo ser.

Excetuando-se às germinativas, todas as outras células fazem o papel de suas guardiãs, por um ciclo de vida programado.

Após o término desse ciclo surge a morte, como resultado do exaurimento da capacidade vital do complexo biológico, via envelhecimento; considerando-se a trajetória natural do ciclo vital.

Nesse sentido, "cada ser humano consciente é um livro, no qual se escreve uma história de vida, com quantidade de páginas em branco equivalente à expectativa de vida dada para um determinado período social".

Segundo a visão jurídica atual, a página inicial começa a ser escrita com o nascimento com vida, ressalvado os direitos do nascituro, e a página final termina com a morte absoluta, que deverá ser escrita sob a ótica perceptiva alheia.

Se considerássemos a morte como um gênero, seria impossível imaginála, conceituá-la ou, até mesmo, fazer-lhe considerações, pois estaríamos diante do nada absoluto. O que se pode extrair do nada absoluto?

Tentar imaginar o nada absoluto seria impossível, ou transportamo-nos, em pensamento, para uma outra dimensão imaginária ou simplesmente imaginamos algo, sempre com a participação de, pelo menos, uma vida, a própria.

Portanto, se nem ao menos conseguimos imaginar o nada absoluto, podemos afirmar, hipoteticamente, que não existe a morte absoluta, considerada como gênero.

A memória genética do organismo humano é a pura essência da vida, portanto como a essência da vida pode viver a morte?

Tentar viver a própria morte ou vivenciar a morte alheia também seria impossível, já que a morte é um estágio de percepção atribuído, somente, às pessoas humanas, ou seja, a percepção da morte é atributo da pessoa humana.

Assim sendo, não se deve confundir a percepção com a vivência perceptiva da morte, ou seja, viver a própria morte ou vivenciar a morte alheia.

Nesse ponto de vista, como se deve conceber a morte?

Devemos restringir os diversos ângulos que a circundam, tomando-se, como exemplo, a morte da pessoa humana, foco desse estudo, e dividi-la nos diversos ramos da Ciência, ou seja, considerações no sentido, médico, sociológico, filosófico, jurídico, religioso, etc. 
Já que não temos a capacidade de viver ou vivenciar a morte, fazem-se necessárias algumas considerações, as que mais se identificam com a nossa proposta, ou seja, a morte no sentido médico, sociológico, filosófico e jurídico.

\subsection{Considerações sobre o sentido médico da morte}

A Tanatologia (thanatos, em grego, significa morte) é a Ciência que estuda o organismo, segundo os efeitos da morte, cujo objetivo é a tanatognose, ou seja, o diagnóstico da morte.

Segundo o entendimento de Evaldo A. D’Assumpção, uma das grandes preocupações que assombram as pessoas humanas é o medo de serem enterradas vivas. Entretanto, a Tanatologia desenvolve-se para que possíveis erros sejam reparados em curtíssimo prazo.

As legislações, de quase todos os países, não permitem o sepultamento imediatamente após a tanatognose, excetuando-se os casos de diagnóstico tardio, quando o corpo se encontra em estado de putrefação, ou quando apresenta lesões incompatíveis com a vida.

Nesse intervalo de tempo, entre a tanatognose e o sepultamento, os sinais da morte se evidenciam, tornando-se praticamente impossível um sepultamento com vida.

Em função dos transplantes de órgãos, a Tanatologia assume vital importância, ao estabelecer, o mais precocemente possível, o diagnóstico da morte, evitando-se que os órgãos assumam o processo natural de putrefação, o que impossibilitaria o seu uso adequado.

Por esse motivo, tornou-se imprescindível a sua evolução.

Há milhares de anos surgiu o primeiro diagnóstico da morte e, segundo estudos arqueológicos, a tanatognose era baseada na imobilidade prolongada seguida de putrefação.

No antigo Egito, já se cultuava e ritualizava a morte, cuja respiração e os batimentos cardíacos já faziam parte da tanatognose.

Hipócrates, na Grécia, associou a imobilidade à palidez, dando origem à fácies hipocrática - a face da morte.

Em 1628, a circulação sangüínea passou a incorporar a tanatognose, mas havia um inconveniente: ao fazer uma incisão num grande vaso sangüíneo, o sangue passaria a jorrar e, se a pessoa não estivesse morta, dificilmente os médicos conseguiriam estancar a hemorragia, o que a levaria à morte. 
Com a invenção do estetoscópio e do microscópio, criou-se a ausculta cardíaca amplificada, que permitia o diagnóstico da morte, mediante o estudo de tecidos do cadáver ao microscópio.

Esse sistema esbarrava em alguns problemas, pois se descobriu que diferentes tecidos possuíam diferentes tempos de vida e, mesmo após várias horas, alguns tecidos revelavam plena vitalidade.

Outro sistema criado era o de introduzir uma agulha longa no tórax, até atingir o coração, que se estivesse em movimento, mesmo não-detectável pelo estetoscópio, faria com que a agulha se mexesse. $\mathrm{O}$ inconveniente era o de produzir lesões graves nesse órgão.

No século XX, com a invenção do eletrocardiógrafo, que detecta com precisão as pulsações elétricas do coração, tal aparelho passou a ser muito utilizado no diagnóstico da morte. Porém, o próprio avanço da Medicina terapêutica constatou que vários pacientes, em silêncio eletrocardiográfico, recuperaram-se, anulando-se, assim, o eletrocardiograma como meio seguro ao diagnóstico da morte.

Surge então o eletroencefalograma, aparelho capaz de medir os impulsos elétricos do cérebro, que revela, ou-não, o silêncio cerebral completo, aceito como sinal seguro da morte de uma pessoa.

A angiografia cerebral, outro recurso utilizado, relaciona o sistema circulatório ao sistema nervoso. Injeta-se contraste na região cervical, seguindo-se de radiografia craniana. Se houver contraste no sistema circulatório do cérebro, há vida; se não houver, não há vida.

No entanto, num rigor científico absoluto, existem raras exceções de pessoas que apresentam silêncio cerebral, e depois de medicadas apresentam novos sinais de vida.

Ficam, esses casos, como alerta para as limitações do homem.

Para o futuro, fala-se em "fotografias Kirlian", para detectar o diagnóstico da morte, ou seja, a gravação da aura que existe em torno do organismo humano, a qual se modificaria com a morte.

Por enquanto esse recurso não foi introduzido como meio oficial para se chegar ao diagnóstico da morte - tanatognose. Mas atente-se para esse recurso, pois, no futuro, poderá servir como método de individualização da pessoa humana via consciência. 


\subsection{Considerações sobre o sentido sociológico da morte}

No sentido sociológico a morte deve ser analisada como um processo natural da vida, pois é o seu momento derradeiro. Nesse sentido citam-se Áurea Starling Albuquerque Penido Silva e Antônio Chaves:

Do ponto de vista social, a morte seria um rompimento irreversível do sujeito (o homem) com os grupos dos quais participa e, conseqüentemente, com o cumprimento dos papéis, por ele assumidos, pela finitude de sua própria natureza biológica. ${ }^{13}$

A personalidade aqui se entende pela capacidade de manifestação individual da alma, espírito ou ser que anima o corpo físico, definindo-a ou afirmando-a. Extingue-se a personalidade no momento em que não há mais possibilidade de se estabelecer esse relacionamento ou contato a nível inteligente com o meio exterior. ${ }^{14}$

Diante da sociedade, a morte deve ser analisada sob dois aspectos distintos.

Num primeiro momento, o período que a antecede, seja ela absoluta, ou relativa, segundo essa linha de estudo.

Nesse momento, o moribundo ao possuir consciência do inevitável, a morte, tenta absorvê-la segundo a sua concepção de vida, aceitando-a ou rejeitando-a.

É o momento em que se reflete, profundamente, sobre o senso crítico do próprio existencialismo, e, também, a preocupação quanto ao futuro da sua família e/ou de outros dependentes.

Num segundo momento, a morte já consumada, mister se faz relatar que essa realidade já não mais pertence ao de cujus, somente ao espectador; pois quem sofre os efeitos da morte são as pessoas envolvidas intimamente a ela.

Todo e quaisquer benefícios, ou prejuízos, sejam financeiros, psicológicos, etc., serão vivenciados e absorvidos pela sociedade.

A morte se diferencia na sociedade pela inexistência do preconceito, ou seja, todos são iguais diante dela.

O que diferencia um de cujus - organismo humano morto, de outro, é o modo de como ocorreu essa morte, e os assessórios agregados ao ritual do sepultamento, cuja sociedade procura-lhe dar status.

\footnotetext{
${ }^{13}$ SILVA, Áurea Starling Albuquerque Penido. Aspecto social da morte. In: D’ASSUMPÇÃO, Evaldo Alves; D’ASSUMPÇÃO, Gislaine Maria; BESSA, Halley Alves, (Orgs.). Morte e suicídio: uma abordagem multidisciplinar. Petrópolis: Vozes, 1984. p. 60.

${ }^{14}$ CHAVES, Antonio. op. cit., p. 57.
} 
4.3. Considerações sobre o sentido filosófico da morte

Antes de quaisquer considerações, devemos citar as palavras de Fédon, que relaciona a filosofia à morte:

"Todos aqueles que retamente se ocupam da filosofia [...] na realidade de nada mais se ocupam que de morrer e estaremos mortos". ${ }^{15}$

No sentido filosófico, devemos entender a morte sob ângulos distintos, mas ligados entre si.

Segundo Alberto Antoniazzi, " a morte traz a necessidade de reflexão sobre algo além da própria existência egoísta, uma viagem além do previsível e do incontestável, e que a filosofia cristã distingue-a como corpo e alma, esta como continuidade da vida".

A morte não se mistura com a vida, é independente, uma não interfere na outra. A morte não interfere na existência da vida.

Nesse mesmo sentido, cita-se a seguir:

Onde está a morte, nós não estamos; onde nós estamos, a morte não está. ${ }^{16}$

A morte não é uma experiência minha, mais que as outras. Além disso, a morte não pode, de jeito nenhum, ser esperada... Porque ela não é senão a revelação da obscuridade de toda a espera, mesmo justamente da espera dela mesma. ${ }^{17}$

A morte tem aceitação quase unânime, e para evitar o seu temor excessivo, diante dessa dura realidade, procura-se dar um propósito a ela. Só assim tornar-se-á suportável.

\begin{abstract}
A meditação da morte, obriga-nos a perceber nossos limites, obriga-nos a superá-los. Ela nos revela a universalidade do ser e sua transcendência com relação ao nosso ser individual. Assim, abre-nos o acesso não de uma vida futura, que conservaria um caráter sempre provisório, mas de uma vida sobrenatural, que penetra e "molha" nossa vida manifestada: não se trata, para nós, nem de adiá-la, nem mesmo de prepará-la, mas de entrar nela, desde agora. ${ }^{18}$
\end{abstract}

\footnotetext{
${ }^{15}$ Fédon apud ANTONIAZZI, Alberto. A morte na abordagem filosófica. In: D’ASSUMPÇÃO, Evaldo Alves; D’ASSUMPÇÃO, Gislaine; BESSA, Haley Alves (Orgs.). Morte e suicídio: uma abordagem multidisciplinar. Petrópolis: Vozes, 1984. p. 54.

${ }^{16}$ Epicuro apud Id. Ibid., p. 55.

${ }^{17}$ Sartre apud Id. Ibid., p. 55.

${ }^{18}$ Lavelle apud Id. Ibid., p. 56.
} 
Tentar o esquecimento da morte é algo incutido na sociedade contemporânea, ao procurar suprimi-la mediante avanços tecnológicos aliados à preservação da espécie humana, evitando-a ou mesmo prolongando-a.

Nesse sentido, a morte não é vista como um acontecimento natural, mas como imposição social.

Devemos destacar, nesse tópico, três situações relacionadas à morte: o rompimento irreversível do homem com a sociedade; a extinção da capacidade da manifestação individual; e a afirmação de que a morte não se mistura com a vida, pois serão alvos de críticas ao compará-las à legislação vigente.

Importante esclarecer, mais uma vez, que, obviamente, a morte não se mistura com a vida, no sentido biológico; e o que se tenta provar é que no sentido jurídico, diante dessas novas relações de vida, a morte não-só se mistura com a vida, como também a confunde.

O Autor abstém-se em fazer considerações sobre os aspectos religiosos, pois entende que existem diversidades de interpretações não pertinentes a essa linha de estudo.

Quanto à indagação inicial, segundo a ordem jurídica atual, a morte apresenta-se como um rompimento irreversível, nos sentidos jurídico e social.

5. Morte relativa: ficção jurídica necessária à nova estrutura de vida

Antes de demonstrarmos esse ponto de vista, segundo o enfoque desse estudo, o leitor deverá centralizar o seu raciocínio à pessoa humana; único bem tutelado no ordenamento jurídico atual, como sujeito de capacidade, direitos e deveres.

Há necessidade, urgente, de se reverem conceitos e convicções, pois a morte passa por profundas modificações diante da evolução humana.

Para o ordenamento jurídico atual o valor consciência é pressuposto para se falar em vida, ou seja, só há vida se houver a exteriorização da consciência.

Por outro lado, quando se fala em morte, fala-se sobre um rompimento irreversível do homem com a sociedade pela qual participa, pela finitude da própria natureza biológica.

Nesse contexto, como podemos aceitar a finitude da natureza biológica de um organismo humano, diante da existência de um fragmento de vida humana, considerado extensivamente - extracorpóreo, preservado vivo e ainda possuir capacidade de alterar o mundo dos fatos, juridicamente relevantes, no futuro? 
Por esse motivo é que surge a morte relativa, que nada tem a ver com os conceitos, até então, conhecidos de morte, pois é uma linha de raciocínio inédita, que possui caráter antagônico aos conceitos atuais; cuja finalidade é alcançar a preservação da dignidade da vida humana.

Nesse ponto de vista, devemos esclarecer e reiterar a proposta de um novo conceito jurídico para a morte, mais adequado às profundas modificações sociais ocasionadas pela evolução da Medicina, com o primeiro questionamento: o que é morte relativa?

Morte relativa é toda forma de vida biológica humana - ser humano, desprovido de consciência, e que possui capacidade mediata imprópria de alterar o mundo dos fatos, juridicamente relevantes, no futuro. É um estado, ou período, neutro em que a vida humana se apresenta, sustentada pelo impulso biológico, aliada, ou-não, ao avanço da Medicina; bem como à probabilidade de um novo estágio relativo à preservação, ao nascimento ou ao renascimento da pessoa humana, objeto final da vida humana.

Podemos dizer que a morte relativa deve ser analisada sob dois aspectos distintos:

$1^{\circ}$ - Morte relativa associada ao indivíduo humano. Nesse caso, tem-se a totalidade do organismo humano privado da exteriorização da sua consciência, aliado ao impulso biológico. Como exemplos, o estado de coma e o estado vegetativo persistente - EVP; também conhecido como síndrome do cativeiro, sintoma que relaciona o aprisionamento da consciência dentro de um corpo.

$2^{\circ}$ - Morte relativa associada aos "fragmentos humanos". Neste caso, têmse extensões de "vidas biológicas fragmentadas", incorporadas ou criopreservadas fora dos seus organismos humanos geradores, sustentadas pelo avanço da Medicina e pelo impulso biológico.

A morte relativa possui o simples objetivo de contemplar a vida humana, no sentido mais amplo, ao contribuir para a possibilidade de um novo estágio para uma pessoa humana que, por sua vez, estará sujeita, tanto em vida quanto na morte, aos efeitos da morte relativa.

A plenitude da vida humana ou a consumação dessa potencialidade máxima, somente é alcançada pela pessoa humana, detentora da vida biológica humana absoluta.

Partindo dessa premissa, devemos considerar, de maneira decrescente, três estágios distintos.

No primeiro, encontra-se a vida biológica humana relativa, ou seja, a impossibilidade de uma pessoa humana manter sua vida dentro da normalidade, seja 
por uma situação física, psíquica ou biológica. Como exemplos, a pessoa com Síndrome de Down (art. 3º, inciso II do Código Civil/2002), os cegos, os tetraplégicos e muitos outros.

Os exemplos citados não se constituem em preconceito, apenas tratamse de questões meramente realistas, pelas quais procuramos dar soluções jurídicas, para abrandar sofrimentos ou, pelo menos, criar novas esperanças.

Esse primeiro estágio não será alvo de estudo, pois se trata de vida humana no sentido relativo.

No segundo, tem-se a morte relativa como despersonalização da pessoa humana, momento em que ela se diferencia em indivíduo humano, cujo valor vida umana respalda-se, exclusivamente, pelo impulso biológico.

Nesse estágio, o que impede a vida absoluta, ou vida relativa, é a ausência de consciência, auto-expressão e autodeterminação. Como exemplos, o estado de coma e o estado vegetativo persistente (EVP).

Importante lembrar que nem sempre esses estados se constituem de rebaixamento absoluto da consciência, e que também não deixaria de configurar o estado de morte relativa, desde que seja impossível decifrar o que a consciência tem a dizer, por meio de palavras ou gestos.

Nesse mesmo sentido é o pensamento de Antônio Chaves:

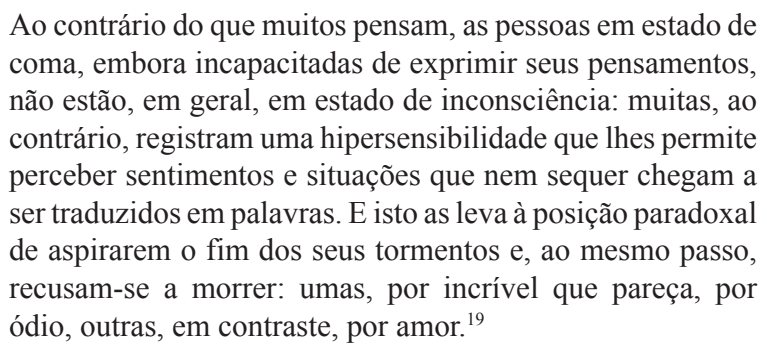

No terceiro, tem-se a morte relativa propriamente dita, inerente aos "fragmentos humanos"; talvez a parte mais polêmica desse estudo.

A primeira linha de raciocínio, que deu origem à escolha da expressão "fragmentos humanos", foi a continuidade da mesma indagação feita para se criar o novo conceito jurídico para a morte, ou seja, "como se pode considerar absolutamente morto um ser humano que, mesmo depois de morto, possui capacidade de alterar o mundo dos

${ }^{19}$ CHAVES, Antonio. Direito à vida e ao próprio corpo: intersexualidade, transexualidade, transplante. São Paulo: Revista dos Tribunais, 1994. p. 75. 
fatos, juridicamente relevantes, no futuro?"; pois possui característica genética-genoma, preservada viva, com plena capacidade de conceber filhos, inegavelmente, legítimos.

Após profunda reflexão, concluímos que a morte relativa não era pressuposto de um organismo humano morto, mas situação integrante de seres humanos vivos, biologicamente, dando-nos o sentido de pedacinhos, ou seja: "fragmentos humanos" em estado de morte relativa.

Para entendermos tal situação, é necessária reflexão profunda sobre o questionamento: o que são fragmentos humanos?

"Fragmentos humanos" são extensões da diversidade de vidas biológicas humanas - seres humanos, mantidos vivos fora dos seus organismos geradores, objetivando a preservação, o nascimento e o renascimento da pessoa humana, objeto de maior alcance da vida biológica humana.

Com relação à palavra preservação, utilizada nesse estudo, devemos entendêla com o seu duplo sentido: o de restauração e o de perpetuação da espécie humana.

Um exemplo clássico, do sentido de restauração, é o transplante de órgãos; e para a perpetuação, a procriação humana pelo método da reprodução assistida (RA).

É fácil observar que os casos citados, só se tornaram possíveis graças ao avanço da Medicina, cujos "fragmentos humanos", em estado de morte relativa, transformaram-se em atributos artificiais que, além da vida biológica humana, restaura a dignidade humana.

\section{Direito Artificial: Instrumento Inerente ao Atributo Artificial}

O Direito Artificial que aqui se estuda cientificamente não possui qualquer vínculo com a Bioengenharia, aquela que traz soluções mecânicas ao corpo humano; nem mesmo ao avanço da informática, aquele que cria uma suposta inteligência artificial, mas aquele inerente ao atributo artificial humano, que traz soluções humanas com métodos artificiais da Medicina, ou seja, um direito que surge, subsidiariamente, amparado pela Medicina, toda vez que o Direito Natural inato se torna impotente diante das inéditas situações oferecidas e impostas pela sociedade.

A expressão Direito Artificial não é nova, mas pelo enfoque desse estudo possui linha de raciocínio inédita, na qual há evolução no sentido da dignidade humana.

Escolhido após profunda reflexão diante de situações jurídicas criadas sem amparo legal, em razão da exigência social, vinculadas ao avanço da Medicina. 
Entendemos ter nascido concomitantemente à cadeia evolutiva dos direitos fundamentais de quarta geração - manipulação genética.

Preocupado com a evolução de tais exigências, assevera Norberto Bobbio:

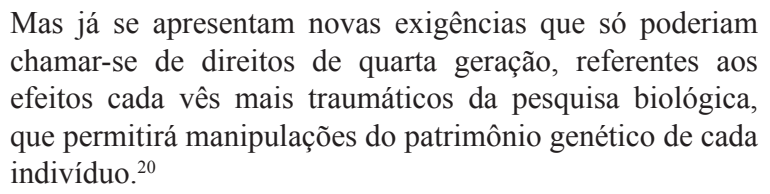

O organismo humano, ao ser considerado extensivamente - extracorpóreo, ou seja, até o limite onde houver sua integridade genética preservada, define uma nova relação jurídica de Direito Artificial; cuja consciência, bilateral ou unilateral, definirá o caminho da responsabilidade jurídica. Ou seja, cada pessoa ou responsável legal, entendido como doador e receptor, deverão direcionar uma finalidade à integridade genética - campo do querer-ser, sempre em benefício próprio ou da Humanidade, jamais descartá-la.

Devem-se destacar, nesse tópico, os casos em que a filiação depende da mãe, ou da barriga, de aluguel; situações em que a nova sistemática considera o complexo biológico alheio como atributo artificial, ou seja: a pessoa humana que gera um filho em nome de outrem, é o próprio atributo artificial.

O Direito Natural vincula um atributo natural, no qual prevalece a natureza humana aliada ao "impulso biológico" inerente à ordem natural das coisas; enquanto que o Direito Artificial vincula um atributo artificial, no qual prevalecem a expressão da consciência e a Medicina, aliadas ao impulso biológico, previamente artificializado.

Logo se conclui que o Direito Artificial é inerente à consciência da pessoa humana - campo do querer ser, não da natureza biológica humana, como pregam os naturalistas vinculados ao Direito Natural, segundo uma ordem natural das coisas. Nesse contexto, a pessoa assume, pela expressão da própria vontade, exclusiva responsabilidade jurídica adversa ao Direito Natural.

É o Direito Artificial assumindo o caráter de desbiologização do Direito.

O Direito Artificial não-interfere no Direito Natural, apenas caminham paralelamente com propósitos convergentes, ou seja: preservar a espécie humana.

Ele é a solução artificial, fornecida pela Medicina, diante da inexistência ou exaurimento da capacidade biológica do Direito Natural inato; cuja identidade e

${ }^{20}$ BOBBIO, Norberto. A era dos direitos. Tradução de Carlos Nelson Coutinho. 9. ed. Rio de Janeiro: Campus, 1992. p. 6. 
integridade genética, do ser humano, devem ser respeitadas como tal, ampliando-se, consideravelmente, o sentido de dignidade.

Como reflexo dos seus atos, a pessoa humana poderá participar, concomitantemente, das duas relações jurídicas: a natural e a artificial, envolvendo-se com sentimentos análogos.

Esses sentimentos são facilmente detectáveis, bastando-se observar o acréscimo do valor solidariedade, amparado pelo sistema contratual altruístico, que se encontra no mundo do querer-ser.

Sabemos que existem várias situações envolvidas com a morte relativa, mas devemos ressaltar que só é possível a sua existência diante de um instrumento imprescindível: o Direito Artificial, cuja união cria uma nova sistemática interpretativa para o Direito: a relação jurídica de Direito Artificial, ao introduzir efetivamente o ramo do Biodireito, no ordenamento jurídico.

7. Morte relativa: um direito artificial

Embora a morte relativa seja inerente ao Direito Artificial, possuem características independentes, que, ao estudá-las isoladamente, não trazem expressivos benefícios à Humanidade.

Devemos entender o tema sob três situações distintas: a morte relativa entendida como um novo conceito jurídico para a morte, mais adequado às profundas modificações sociais, diante do avanço médico-científico; o Direito Artificial visto como um direito, propriamente dito, ou seja: o direito de querer, ou possuir, alguma coisa; e o Direito Artificial entendido como uma Ciência autônoma, vinculada ao atributo artificial humano.

Contudo, para a linha de raciocínio que apresentamos, devemos analisálas conjuntamente, pois ao se unirem assumem o papel de transformar a vida humana no contexto jurídico-social, ao criar uma nova sistemática de raciocínio interpretativo para o Direito, embasada pela relação jurídica de Direito Artificial.

Relação, esta, que não se estabelece no campo do ser ou do dever-ser, pois se trata de uma relação sui generis, tão somente instituída no campo do querer-ser. Não um "querer-ser" ao nível individual e egoísta, mas aquele amparado e alicerçado pelo "sistema contratual-altruístico".

A seguir, demonstraremos, em alguns exemplos, a relação íntima dessa nova sistemática com a evolução da Medicina. 


\subsection{A sistemática e o avanço da Medicina}

Estamos diante de possíveis revelações, que deixarão a sociedade perplexa e o mundo jurídico de mãos atadas.

Pelo menos, uma vez, ouvimos as seguintes expressões: estado de coma ou vegetativo; criopreservação de gametas; transplantes de órgãos; reprodução assistida; clonagem; células-tronco; aborto; etc.

Pois bem, acreditem ou-não, todas essas situações têm, ou terão, profunda ligação com a sistemática proposta.

Devemos observar alguns questionamentos e considerações, sobre cada uma das situações supramencionadas.

\subsubsection{A sistemática, o estado de coma e o estado vegetativo}

É relevante, nesse momento, que se diferencie o estado de coma, do vegetativo, cujas informações foram extraídas do site: www.gerenciadeprogetos.com/ coma, e escolhida por retratar situações de maneira que pessoas leigas, salvo exceções, pudessem assimilar.

Os livros de Medicina, no ramo da neurologia, conceituam a palavra coma como sendo: "o estado de falência dos mecanismos que mantêm a consciência", e a consciência como "um estado de perfeito conhecimento de si próprio e do ambiente".

A consciência é uma das funções do nosso cérebro, e é caracterizada por dois componentes distintos: o nível (grau de sensibilidade para a vida, ou seja, o quanto a pessoa está perceptiva aos acontecimentos), e o conteúdo (somatória dos conhecimentos dessa sensibilidade); é o que caracteriza a pessoa humana.

O coma é um estado patológico - não faz parte da normalidade da vida, de rebaixamento do nível de consciência, que induz organismo estático, cuja presença da pessoa humana, ou do indivíduo humano, definir-se-á pelos resultados dos exames médicos, ao demonstrarem respostas, ou-não, aos estímulos.

No estado vegetativo, também conhecido como estado vegetativo persistente (EVP), há, também, o rebaixamento do nível de consciência, cujo indivíduo humano apresenta movimentos lentos, dando a impressão de que está consciente, o que não é verdade, visto que esses movimentos são executados pelas funções vegetativas do cérebro, ou seja, funções que se realizam sem a dependência da consciência, como a respiração, os batimentos do coração, a deglutição, o abrir e o fechar dos olhos, os movimentos oculares aleatórios, etc. 
Excetuando-se as particularidades de cada estado patológico, é a consciência que determina o grau de sensibilidade da pessoa humana para a vida.

No sentido jurídico, se não há consciência não há vida; se não há vida, não há pessoa humana; e se não há pessoa humana, há a morte absoluta ou a morte relativa, esta, exprimindo, mesmo que temporariamente, a origem do indivíduo humano, que se ampara, exclusivamente, pelo impulso biológico.

Tem-se, nesse caso, a morte relativa em decorrência da despersonalização da pessoa humana, ou seja, a transformação do organismo humano, consciente, em indivíduo humano, em razão da ausência ou impedimento da consciência.

O que devemos entender é que a presença da consciência, por menor que seja, detectável em um organismo humano, apenas diferencia pessoa humana de indivíduo humano; relevante para o Direito Penal, quanto à tipificação da prática da eutanásia, por exemplo, ao configurar crime ou-não; contudo não os livram do estado de morte relativa, desde que não se consiga identificar, ao nível inteligível, o verdadeiro sentido á qualquer expressão.

Nos casos expostos aplicam-se à nova sistemática, no momento em que a totalidade do organismo humano, em estado de morte relativa, depende do Direito Artificial, via atributo artificial, como instrumento de sustentação da própria vida.

Essa nova sistemática, relação jurídica de Direito Artificial, dá o direito de opção quanto à interrupção da vida, sem prejuízo à Humanidade, no caso das doações dos "fragmentos humanos", por exemplo: órgãos; ou quanto à luta incessante para readquirila.

Quaisquer das situações dependerão da pré-autorização do moribundo, ou efetivar-se-á com autorização alheia, no caso do responsável legal.

Dando amparo a essa linha de raciocínio, cita-se:

Também se argumenta que o Estado nem a Igreja Católica não são os donos da vida da pessoa, e por isso a coletividade não pode obrigar ninguém a viver contra a própria vontade. Existe sim um direito à vida, e não, uma obrigação á vida. ${ }^{21}$

${ }^{21}$ Sztajn apud TOMASEVICIUS FILHO, Eduardo. Direito civil entre a vida e a morte. Revista da Faculdade de Direito da Universidade de São, São Paulo, v. 100, p. 459, jan./dez. 2005. 


\subsubsection{A sistemática e a criopreservação de gametas}

Não existe, no Brasil, lei sobre doação de gametas, há somente uma resolução do CFM, n. 1.358, de 11 de novembro de 1992, regulamentando as normas éticas para a utilização das técnicas de reprodução assistida (RA), na qual prepondera, acima de tudo, o anonimato entre doador e receptor.

Extraímos informações do site www.virtual.epm.br/cursos/genética/htm/ gametas (Escola Paulista de Medicina), para explicar, mesmo de maneira simplista, o que são gametas? E o que é criopreservação?

Gametas são os núcleos celulares das células sexuais masculinas - espermatozóides, e femininas - óvulos. São células germinativas sexuais altamente especializadas, que possuem metade do número total de cromossomos - 23; estes detentores do fator da hereditariedade, ou seja, é a individualização biológica do organismo humano.

Já a criopreservação é um processo de congelamento para evitar danos, no qual os gametas recebem adicionamento do glicerol, posteriormente armazenados em nitrogênio líquido, a uma temperatura de $196^{\circ} \mathrm{C}$, negativos, por tempo indeterminado.

Indiscutível o questionamento quanto à característica genética individual do organismo que gerou os gametas doados e criopreservados.

Sabemos que a prole é uma conquista da união de duas pessoas, na qual estão envolvidos sentimentos, instintos, vontades, determinações, aliados à capacidade física, psíquica e biológica, estas como requisitos essenciais para se chegar à sonhada conquista; considerando-se tais argumentos como forma natural de constituição familiar.

De outra forma, não-natural, casais, ou pessoas independentes, recorrem ao sêmen, aos óvulos ou aos embriões, alheios, ou-não, com a finalidade de concepção via reprodução assistida (RA).

Quando doados e criopreservados os gametas, ou embriões, quaisquer desses requisitos, ou seja, os sentimentos, os instintos, as vontades e as determinações, considerados individualmente, ou-não, passaram-se pela consciência desse doador, mas de modo análogo aos requisitos para a constituição da própria prole, constituindo-se uma nova relação jurídica de Direito Artificial.

Nesses termos, ao desconsiderar-se essa nova relação, aliada à falta de legislação específica, hoje: "todo doador é signatário de um legado tácito da preservação da própria espécie, ao assumir todos os riscos inerentes ao ato praticado". 
Aplica-se a nova sistemática como possibilidade dessa abertura sucessória, sem prejuízos quanto às conseqüências futuras de uma vinculação jurídico-biológica, ao se demonstrar que a Biologia, nesse caso, é apenas meio indispensável para efetivação do contrato altruístico, previamente acordado.

\subsubsection{A sistemática e os órgãos}

Delicado, nesse estágio da evolução humana, fazermos uma correlação mais estreita entre um órgão doado, considerado, nesse estudo, como extensão da vida humana, e essa nova sistemática.

O que se sabe de concreto, nesse momento da evolução humana, é a existência de órgãos criopreservados ou transplantados, estes agregados à vida de outros organismos humanos, aqueles aguardando seu destino final. Nesses casos, tem-se a solidariedade contribuindo para a preservação da vida humana.

Tal solidariedade é amparada por um fundamento filosófico popular, segundo o qual, os familiares no ato da consumação da doação dos órgãos, envolvidos por sentimentos maiores, expressam-se: de alguma maneira ele (a) sobrevive.

Sempre mantivemos o pensamento de que expressões usadas com a pureza da sensibilidade, campo da essência da vida humana, teriam fundamentos concretos.

Numa programação da Rede Globo/Fantástico, mais precisamente no dia 15/05/2005, foi veiculada matéria com o título: "Memória no transplante de figado", que dá suporte a essa linha de pensamento.

Gary Schwartz, médico norte-americano, tenta demonstrar que as células e órgãos podem guardar e transmitir algum tipo de memória, em razão de uma espécie de energia que circula pelo corpo; originando-se no coração e relacionada às nossas emoções, ao levar informações a todas as células do organismo.

Ele expressa o seguinte pensamento: "Emoção é energia em movimento, ela pode estabelecer ligações biofísicas".

Cita no seu estudo dois exemplos de transplantados, um de fígado e outro de coração, que começaram a ter manifestações biológicas e psíquicas coincidentes com as dos doadores, chegando a ponto de fazer a seguinte afirmação:

Explicações meramente biológicas são insuficientes para entender esses fatos bizarros. Essas memórias dos 
A origem do Biodireito universal

Morte relativa: um Direito Artificial, uma nova sistemática interpretativa para o Direito

transplantados sugerem a possibilidade de continuidade da consciência mesmo depois da morte. ${ }^{22}$

Por enquanto não há comprovação científica de que algo assim possa acontecer, mas fica como alerta, pois a evolução da Medicina reservou-nos grandes surpresas, que outrora eram utópicas.

Devemos lembrar que os clones nascidos de animais foram concebidos a partir de células somáticas - células do corpo, e não de células sexuais.

Considerando-se que os órgãos humanos também são passíveis de extração de células somáticas, cabe uma indagação: haverá possibilidade de clonagem do doador do órgão, a partir de células somáticas extraídas do órgão já transplantado?

Ainda não se têm respostas para essa indagação, mas para a maioria dos cientistas é tecnicamente possível.

$\mathrm{O}$ que se sabe, no tocante à clonagem humana, é que na modalidade terapêutica apresenta limitações, ou seja, só é possível fazê-la se forem usados óvulos e células somáticas de uma mesma pessoa do sexo feminino. ${ }^{23}$

Por hora, podemos assimilar, paradoxalmente, a nova sistemática no sentido sentimental, em decorrência da extensão dos “fragmentos humanos”, via autorização própria, ou do responsável legal, agregados a um novo organismo humano, com sentimento de continuidade da vida fragmentada.

Em outro sentido, não devemos esquecer que existe uma correlação inerente ao processo da vida humana, que são os direitos-deveres.

A partir do momento em que a Medicina ofereceu à sociedade o direito ao "atributo artificial" como meio de preservação da vida humana, cuja sociedade aceitou-o como um "direito legítimo"; passou a aceitá-lo, também, como um dever legítimo.

Nesse sentido, a sociedade assumiu o compromisso do dever inato para com a vida humana, que não se deve confundi-lo como ato obrigatório - imposto pela sociedade; ou ato compulsório - prevalência da força do Estado sobre o indivíduo.

Ambas as situações, acima, privam o direito ao livre arbítrio. Contudo, essas novas relações de vida, no mesmo instante em que reafirma o direito ao livre arbítrio, vincula-o ao direcionamento vital, segundo o interesse do consciente justodigno-altruísta, ou seja, a pessoa humana deve escolher um direcionamento à integridade

\footnotetext{
22 SCHWARTZ, Gary. Memória no transplante de figado. Fantástico. Disponível em: < http://www.fantastico. globo.com/Portal/jornalismo>. Acesso em: 12 jun. 2005.

23 TOMASEVICIUS FILHO, Eduardo. op. cit., p. 448.
} 
biológica, segundo as opções oferecidas pela Medicina, jamais descartá-la, sob pena de responsabilizar-se pelo crime de omissão de socorro impróprio.

Nesse sentido, as doações de órgãos tornaram-se inatas, ou seja: transcenderam às convicções do livre arbítrio individualista, cujos direitos-deveres, simplesmente, incorporaram-se ao processo vital em favor da vida humana.

Acreditamos que a divulgação responsável desse estudo inicial poderá contribuir, de maneira relevante, para o aumento das doações de órgãos no País, até que a sociedade assimile esse estudo e o aceite como condição inerente ao processo da preservação da vida humana.

Temos absoluta convicção de que a vida humana agradecerá!

\subsubsection{A sistemática e a reprodução assistida (RA)}

A reprodução assistida (RA), disciplinada pela Resolução n. 1.358, de 11 de novembro de 1992, do CFM; regula padrões éticos em que prepondera o anonimato dos doadores e receptores.

É imperiosa uma reflexão sobre os aspectos intimidade e anonimato, pois alguns autores dizem que a sua violação ataca, diretamente, os Direitos e Garantias Fundamentais, acolhidos pelo Texto Constitucional, como Cláusulas Pétreas.

Intimidade (s.f.) qualidade do que é íntimo, essencial. Relações íntimas: ter intimidade com alguém. Na intimidade, em família, entre amigos íntimos. ${ }^{24}$

Íntimo (adj.) 1. Que tem estreitas relações de amizade. 2. Caracterizado por amizade cordial. 3. Estritamente pessoal, privado. 4. Que sugere privacidade ou intimidade. 5. Que está na parte mais íntima ou profunda. 6. Detalhado e obtido durante muito estudo ou experiência. 7. Estreitamente ligado // s.m.(o) 8. O que há de mais profundo numa coisa; a parte mais profunda de um ser. 9. Amigo íntimo. ${ }^{25}$

A intimidade possui dupla acepção: a privacidade individualista do ser consigo mesmo, que abrange os sentidos, físico, psíquico e biológico; ou vinculada ao relacionamento de privacidade íntima, ou estreita.

Anonimato (s.m.) Estado do que não tem nome ou que o esconde. ${ }^{26}$

\footnotetext{
${ }^{24}$ SEGUIER, Jaime de. Dicionário prático ilustrado. Porto: Lello \& Irmão, 1961. p. 681.

${ }^{25}$ SACCONI, Luiz Antônio. Minidicionário Sacconi da Língua Portuguesa. São Paulo: Atual, 1998. p. 403.

${ }^{26}$ BUENO, Francisco da Silveira. op. cit., p. 66.
} 
O anonimato possui, também, dupla acepção: o sentido de não-identificação, ou o de esconder-se, acovardar-se.

Entendemos que o anonimato deva existir no sentido de não tornar pública uma situação de intimidade peculiar; como as ações respaldadas pelo segredo de justiça.

No momento em que uma pessoa humana doa o sêmen, para fins reprodutivos, por exemplo, ela encerra o vínculo biológico da própria intimidade individualizada, e transfere-a para a intimidade biológica vinculada.

A partir desse momento não há de se falar em anonimato entre os envolvidos, pois se criou um vínculo estreito de intimidade biológica, cuja responsabilidade biológica, recíproca, é indiscutível.

Contudo, trabalha-se com vida humana, que em tese não possui capacidade jurídica, cujos “fragmentos humanos" próprios, ou alheios, criopreservados e indispensáveis para a perpetuação da espécie humana; ao serem utilizados por pessoas ou casais inférteis, auxiliam-lhes na amplitude da dignidade existente, ao concretizar, outrora esperança, a concepção de uma nova vida humana.

Nenhum médico, ou jurista, duvida quanto à paternidade ou maternidade biológica dos doadores; nesse sentido, extrai-se do site: www.epoca.com.br, trechos da reportagem de Cristina Segatto, feita em 05/08/2002, que sustenta esse ponto de vista.

\begin{abstract}
A primeira leva de crianças brasileiras geradas por mulheres solteiras e sêmen doado tem cerca de 9 anos. É cedo para que procurem na justiça a identificação do pai biológico, mas essa demanda pode surgir, a exemplo dos Estados Unidos, e de países europeus, como Inglaterra e Suécia. $\mathrm{Na}$ falta de Legislação explícita, os juristas brasileiros, tendem a dar ganho de causa aos filhos dos bancos de esperma. 'As crianças têm o direito de conhecer sua origem e pleitear herança dos doadores', diz o jurista José Celso de Camargo Sampaio, estudioso das implicações da inseminação artificial no Direito de Família. ${ }^{27}$
\end{abstract}

Portanto, como já dissemos, a pessoa humana é signatária de um legado tácito da preservação da própria espécie, ao assumir todos os riscos inerentes ao ato praticado, ou seja, a falta de legislação específica faz com que a pessoa assuma, no futuro, todas as conseqüências que dele possam advir, com embasamento puramente biológico (DNA).

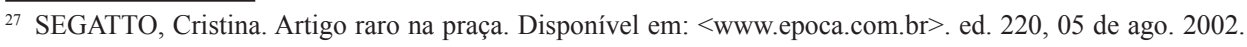
Acesso em: 26 jul. 2005. 
Esse é um exemplo clássico de responsabilidade jurídico-biológica ilimitada no sentido universal, ou retroativa no sentido específico, que se evidencia mais claramente no caso do de cujus.

Não há de se falar em anonimato entre doador e receptor, pois ao se aplicar a nova sistemática, demonstrar-se-á que doadores de sêmen, ou óvulos, devem possuir segurança jurídica quanto aos seus atos praticados, ao relacioná-los expressa e formalmente num sistema contratual altruístico, com força de coisa julgada.

Esse novo sistema contratual não se subordina ao Direito pela trilogia: capacidade, licitude e legalidade formal, mas tão-somente pela supremacia vital, cuja capacidade e licitude é inata à vida humana, e a legalidade se apresenta, não pela forma institucionalizada, mas pela dinâmica das possibilidades apresentadas, segundo um consciente justo-digno-altruísta.

Nesse sentido, o sistema contratual altruístico deve ser entendido como a dinâmica das possibilidades apresentadas, vinculada ao consciente justo-digno-altruísta.

Importante observar que doador e receptor possuem peculiaridades sui generis: o doador poderá apresentar-se de fato - responsável biológico, e de direito representante legal; já o receptor também o será: de fato - fruto da solidariedade, e de direito - responsável (is) por geri-lo.

Nesse sentido, entendemos que pais e filhos relacionados a vínculos biológicos não devem se responsabilizar mutuamente por quaisquer vínculos de parentesco, apenas reciprocidade sobre questões de responsabilidade biológica, se for o caso.

As expressões pais e filhos, por estarem envolvidas com sentimentos maiores, deverão ser substituídas por genitor biológico solidário e fruto da solidariedade, respectivamente, devendo constar, expressa e formalmente, na certidão de nascimento, como meio oficial de identificação pessoal e biológica.

A missão desse estudo, como dissemos anteriormente, não abrange questionamentos críticos sobre os aspectos morais, éticos ou religiosos, relacionados à legislação vigente, apenas destaca situações como fatos biológicos relevantes ao mundo jurídico, apresentando-se soluções segundo uma nova concepção jurídica.

\subsubsection{A sistemática e a clonagem humana}

Para correlacionarmos a clonagem à nova sistemática, proposta nesse estudo, devemos começar respondendo dois questionamentos: o que é clonagem? E como ela é processada? 
As informações, a seguir, foram extraídas do entendimento dos sites: $w w w$. suapesquisa.com/clonagem e www.escolavesper.com.br/clonagem.

Clonagem é um método científico e artificial de reprodução, em que se utiliza o núcleo da célula somática - células de um organismo, em substituição ao espermatozóide, e introduzi-la num óvulo anucleado - célula germinativa feminina sem o núcleo.

Supostamente, seria a criação de uma cópia geneticamente idêntica do indivíduo que foi alvo da extração da célula somática.

Ainda não se têm notícias sobre a clonagem de uma pessoa humana mas, segundo a maioria dos cientistas, é tecnicamente possível.

Alguns questionamentos suscitam-se, relacionados ao provável fato: quem serão os pais biológicos do clone? - ter-se-á dupla identificação para uma mesma identidade genética? - ele será objeto de direitos e obrigações no mundo jurídico-social, em grau de equivalência ao ser copiado? - o receptor do órgão tem o direito à apropriação da integridade genética alheia, e impedir que se faça um clone dessa integridade genética alienígena? - será possível extrair células somáticas de órgãos transplantados, com intuito de se fazer um clone do doador? - etc.

E quanto ao rumo que será dada à consciência primitiva? Será restabelecida? Ou co-estabelecida? Caso seja: poder-se-á afirmar que o organismo biológico define a individualização de uma consciência una e divisível? Ou, caso não seja, provar-se-á que a consciência é individualizada e o organismo biológico é apenas um veículo de expressão aleatório? nesse sentido fortalecerá os dogmas religiosos? Quem sabe?

Enfim, são questionamentos que em médio prazo farão parte de nossas vidas.

Nessa hipótese, entendemos que a nova sistemática é aplicada no sentido de se vincular o agente ativo que impulsionou a criação do novo ser, descartando-se qualquer vínculo biológico.

O importante, por enquanto, é que se visualize sua provável presença, como conseqüência da "capacidade" que possuem os "fragmentos humanos" de replicar a vida biológica humana.

\subsubsection{A sistemática, os embriões e as células-tronco}

Há vida no momento da concepção?

Antes de responder a essa pergunta, faz-se pertinente demonstrar o antagonismo na Legislação brasileira, entre a Convenção Americana dos Direitos Humanos 
de 22/11/1969, ratificada pelo Brasil, em 25/09/1992, e a Lei de Biossegurança n. 11.105, de $24 / 03 / 2005$.

A Convenção Americana estabelece o seguinte:

Art. $1^{\circ}, 2$. Para os efeitos desta convenção, pessoa é todo ser humano.

Art. $4^{\circ}, 1$. Toda pessoa tem o direito de que se respeite sua vida. Esse direito deve ser protegido por lei e, em geral, desde o momento da concepção. Ninguém pode ser privado da vida arbitrariamente.

Convém destacar a impropriedade, contida no art. $1^{\circ}$, inciso 2; ao afirmar que pessoa é todo ser humano, pois a pessoa humana, como dissemos anteriormente, é um organismo humano, com vida biológica, dotado de consciência, auto-expressão e autodeterminação; que na linguagem filosófica significa o ser humano inteligente que se orienta teleologicamente, ou seja, busca um objetivo vinculado à consciência, cujo atributo pertence somente à pessoa humana.

Devemos observar que a recíproca não se faz verdadeira, ou seja, todo ser humano é pessoa humana, pois o sêmen, por exemplo, é uma espécie de ser humano que se orienta, não pelo vínculo da consciência, mas tão-somente pelo impulso biológico da procriação; uma espécie de Teleologia Biológica predeterminada.

Nesse sentido, seria o mesmo que aceitar duas pessoas humanas contidas num mesmo organismo humano, no caso de um transplantado.

Destacamos, também, a impropriedade contida no art. $4^{\circ}$, inciso 1 , do mesmo texto, ao transmitir pessoalidade ao embrião, ao dizer que ninguém pode ser privado da vida arbitrariamente, ou seja, ninguém é um pronome indefinido, que, nesta oração, atribui-se à pessoa humana.

Já a Lei de Biossegurança, antagonicamente, permite o uso de determinados embriões em pesquisas com células-tronco, que são extraídas no intervalo de catorze dias; cujos artigos, foram objetos de Ação Direta de Inconstitucionalidade no Supremo Tribunal Federal (ADIn 3.510), e que contrariam alguns princípios da Convenção Americana, pois denota o imenso despreparo humano-legislativo no tocante ao verdadeiro significado do valor vida, que não pode ser alvo de antagonismos, pois existe um gênero que jamais admite equívoco, e para quem não o conhece chama-se, simplesmente, Vida.

Voltando-se ao tópico, devemos ter noção pouco mais aprofundada sobre as células-tronco. 
Nesse sentido, extraímos questões relevantes da entrevista realizada, em 10 de maio de 2004, pelo médico Dráuzio Varella com Mayana Zatz, professora titular de Genética da Universidade de São Paulo.

Além do poder de auto-replicação que as possuem, ou seja, são capazes de reproduzirem cópias de si mesmas, diferenciam-se nos 216 diferentes tecidos do organismo humano.

São encontradas em diversos tecidos como: cordão umbilical, embrião, cérebro, medula óssea, líquido amniótico, etc.

$\mathrm{O}$ alvo de maior questionamento está relacionado às células-tronco embrionárias, extraídas a partir da fecundação do óvulo pelo espermatozóide - embrião, no período de divisão celular: entre 32 e 64 células (a partir do $5^{\circ}$ dia de vida), denominadas totipotentes ou pluripotentes.

A questão mais relevante evidencia-se sob três aspectos distintos: no primeiro, tem-se a invasão da integridade genética de dois seres humanos, o doador do espermatozóide e a doadora do óvulo; no segundo, a invasão da integridade genética de um ser humano em potencial, fruto da concepção artificial; e no terceiro, a incerteza do momento em que é acrescido ao embrião o valor "consciência", este soberano e inviolável.

Como dissemos anteriormente, as instituições relacionadas à vida, embora, absolutamente, alheias à "linhagem vital”, digladiam-se sobre discussões quanto ao início da vida humana, que se resumem em sete vertentes básicas:

$1^{\text {a }}$-Na concepção, ou seja, na fecundação obtida pela fusão do espermatozóide e óvulo, originando-se o embrião (detentora da corrente majoritária);

$2^{\mathrm{a}}$ - Na nidação, ou seja, é o momento em que o embrião se fixa à parede do útero;

$3^{\mathrm{a}}$ - Em 14 dias - duas semanas, ou seja, a vida começa com a formação do cérebro;

Nesse sentido Antônio Chaves, ao citar Maria Celeste Cordeiro Leite dos Santos, traz como argumento decisivo a inexistência de qualquer estrutura neural - esboço neural - no embrião antes de 14 dias de vida:

[...] ser quatorze dias a cifra de ouro da embriologia humana, seja do ponto de vista da relação embrião-mãe (implantação, 
de individualização, da circunscrição (disco embrionário) ou de Humanidade (esboço neural). ${ }^{28}$

$4^{a}$ - Após a $9^{a}$ semana, ou seja, com a formação do feto, o ser humano começa a possuir uma aparência de pessoa humana, com membros e órgãos;

$5^{\mathrm{a}}$ - Entre a $6^{\mathrm{a}}$ e $10^{\mathrm{a}}$ semanas, ou seja, com a implantação da atividade cerebral.

$6^{\mathrm{a}}$ - Entre a $25^{\mathrm{a}}$ e $32^{\mathrm{a}}$ semanas, ou seja, no início da atividade organizada do córtex cerebral. Nesse sentido:

É a partir dessa altura que as ligações sinápticas entre células cerebrais individuais começam a estabelecer-se - até esta altura, essas células eram pequenas ilhas, por assim dizer. Começa a ser possível captar as ondas cerebrais do feto através do eletro-encefalograma. Argumentavelmente, é sensivelmente a partir desta altura que o feto começa a pensar e a ter consciência, algo que tanto um ser humano adulto como um bebe recém-nascido têm (embora em graus diferentes, obviamente). ${ }^{29}$

$7^{\mathrm{a}}$ - No nascimento.

Importante salientar, mais uma vez, que em nenhum momento falou-se sobre a possibilidade da vida humana anteceder a toda essa discussão.

Nem se questiona o porquê do Direito tutelar somente uma espécie de vida humana - a pessoa humana, e, amparando-se numa premissa menor, diante de sua impotente arrogância, ousa disciplinar uma premissa maior - a vida humana.

Não podemos fechar os olhos ao impulso biológico e imaginar que a consciência seja inserida no momento da concepção, pois a anencefalia é um exemplo de concepção com prevalência exclusiva do impulso biológico.

A Medicina já provou, em nível mundial, considerando-se os aspectos puramente científicos, a absoluta convicção quanto à ausência da consciência até os catorze dias após a concepção, cujo prazo, considerando-se outras situações, poderá até ser estendido.

Nesse período há sim uma espécie de vida humana, um fragmento de vida humana, por assim dizer, e nos ensinamentos de Aristóteles há uma potencialidade forte.

\footnotetext{
${ }_{28}$ Santos apud CHAVES, Antonio. Direito à vida e ao próprio corpo: intersexualidade, transexualidade, transplante. São Paulo: Revista dos Tribunais, 1994. p. 197.

${ }^{29}$ MADEIRA, Pedro. Crítica. Disponível em: <http://www.criticanarede.com/aborto_1_htm>. Acesso em: 30 mar. 2007.
} 
Os obstáculos contidos nessa guerra que se trava entre essas instituições, pendem para a dogmática religiosa, que antagonicamente luta pela preservação dos "fragmentos humanos" em detrimento da pessoa humana, que é o objeto final da vida humana.

Portanto, considerando-se as conseqüências desse estudo, a resposta para a indagação formulada no primeiro parágrafo é a seguinte: para o Direito não há vida, pois não há expressão da consciência; e para a Medicina há vida no sentido estritamente biológico.

Aplica-se a nova sistemática à situação das células-tronco, e nada mais adequado que autorização expressa, amparada por lei especial, segundo a nova modalidade contratual, proposta nesse estudo - sistema contratual-altruístico, em analogia à doação de órgãos duplos em vida, ou a pré-autorização dos órgãos post mortem, para que a invasão da integridade genética passe a ter finalidade expressamente predeterminada.

No enfoque da legislação atual, ao se falar de embriões - "fragmento humano", é importante observar que, segundo a concepção naturalista, a Teleologia admite a procriação como última finalidade; contudo, segundo a visão artificialista desse estudo, ela pode admitir, para esse mesmo embrião, a preservação humana como última finalidade.

Aplica-se a nova sistemática no sentido de se demonstrar que a pessoa humana, via "sistema contratual-altruístico", deve direcionar uma finalidade à própria integridade biológica, cabendo ao Direito, apenas, criar condições à sua legalização, caso contrário tratar-se-á de fato atípico.

\subsubsection{A sistemática, o aborto e a vida biológica humana desprovida de consciência}

Um tema que até os dias de hoje polemiza a sociedade mundial, talvez provocada pela própria estrutura defasada do Direito.

Há de se lembrar que o Direito e a Medicina, no tocante ao aspecto vida, não sintonizam a mesma linguagem, ou seja, para o Direito, ela é inerente à expressão da consciência, que induz capacidade e personalidade jurídica; para a Medicina, ela tem acepções mais amplas, cuja biologia humana, por si só, não atende aos requisitos da tutela jurisdicional.

Convém relembrarmos que o aborto está inserido na parte especial do Código Penal de 1940, e ao obedecer à técnica de hierarquia entre capítulos e títulos, dever-se-á entendê-lo como "Dos Crimes Contra a Vida da Pessoa". 
No sentido estritamente técnico, não há de se falar em aborto sobre uma vida biológica humana, quando não houver a presença da consciência, pelo simples fato de não haver pessoa humana.

Os debates que possam existir sobre o aborto ou qualquer outra situação em que haja envolvimento de uma vida humana, desprovida de consciência, devem ser realizados harmonicamente e em nível igualitário, sem que uma instituição se sobreponha à outra, pois as Ciências e a Religião perderam o foco e a capacidade de amparar o objetivo maior, o valor vida humana.

O que se precisa é que haja maior respeito e entendimento entre o Direito, a Medicina e a Religião, ao interpretarem uma mesma linguagem vital, e aplicá-la uniformemente com o intuito exclusivo de se atender os propósitos da Vida.

Só assim cada uma poderá exercer o seu objetivo com legitimidade, respeito e soberania, cujos meios, embora absolutamente diversos, vincular-se-ão a um só propósito.

Aplica-se a nova sistemática no sentido de se demonstrar, tecnicamente, que não há de se falar em imputação quanto ao crime de aborto sobre uma vida humana desprovida de consciência; pois o que há de verdade é uma interrupção da vida biológica humana, fato atípico pertencente às novas relações de vida - campo do "querer-ser", instituídas nas relações jurídicas de Direito Artificial.

\section{A sistemática e a legislação vigente}

A Constituição Federal, o Direito Civil, o Direito Penal etc., nos dias atuais, possuem vínculos, pessoais e biológicos, que serão inadequados ou insuficientes diante das novas exigências sociais.

O ordenamento jurídico tutela, como bem maior, a vida da pessoa humana, contrariando a linha de pensamento tripartite usada como instrumento propulsor desse estudo.

A Constituição Federal, de 1988, no seu Título I (Dos Princípios Fundamentais) no art. $1^{\circ}$, inciso III, tutela o Princípio da Dignidade da Pessoa Humana, e não o "Princípio da Dignidade da Vida Humana", este mais abrangente que aquele.

Quando se fala em dignidade, no sentido literal, fala-se sobre idéias, sentimentos ou atos amparados por grande teor de nobreza, o que não ocorre com a Constituição, de 1988 , cujo art. $5^{\circ}$ ao tratar da dignidade, não a faz como essência, mas como mero objeto de conquista, o que faz da pessoa humana apenas um instrumento 
necessário à procura de uma dignidade que não lhe pertence e, ao mesmo tempo, corre-se o risco de não a encontrar.

A dignidade, proposta nesse trabalho, ampara a vida como essência de si mesma, independe de conquista, ao contrário, onde há vida deve haver obrigatoriamente dignidade.

“A vida humana é apenas uma das conquistas do gênero Vida, e a dignidade a sua razão de ser".

O Código Civil, de 2002, em sua Parte Geral, Livro I (Das Pessoas), Título I (Das Pessoas Naturais), Capítulo I (Da Personalidade e Da Capacidade), atribui, no art. $1^{\circ}$, capacidade à pessoa e, no art. $2^{\circ}$, atribui-lhe personalidade.

Há, nos casos, redundâncias, pois no sentido jurídico a pessoa já é o ser dotado de personalidade e capacidade, seja relativa ou absoluta, dando-nos um sentido de vida relativa ou de vida absoluta.

A incapacidade acolhida pelo Direito não tem qualquer vínculo com a essência do ser humano que, na maioria dos casos, já nasce dotado de capacidade e personalidade, apenas são inadequadas ao mundo jurídico, por demonstrarem restrições formais no modo de exprimirem a manifestação da consciência.

Por outro lado, existem outras espécies de vidas humanas que apresentam uma nova modalidade de capacidade - a capacidade mediata imprópria, ou seja, dependem de intervenção médica; cuja falta de legislação adequada, transmitirá, retroativamente, ao ser responsável, biologicamente, capacidade e personalidade adequando-as ao mundo jurídico.

Éa capacidadebiológica com responsabilidade ilimitada ou responsabilidade retroativa, que se evidencia mais claramente no caso do de cujus.

O Código Penal brasileiro, de 1940, na sua Parte Especial, Título I (Dos Crimes Contra a Pessoa), Capítulo I (Dos Crimes Contra a Vida), tutela, também, a vida da pessoa, visto que o Capítulo I obedece à hierarquia do Título I, situação que deve ser entendida como: "Dos Crimes Contra a Vida da Pessoa".

Se alguém disser que o ordenamento jurídico já ampara o gênero vida humana, poderemos afirmar que a maioria das pessoas humanas é criminosa, ao recusar-se socorrer alguém, biologicamente, que clama pela própria vida; por indiferença, desprezo, egoísmo ou ignorância.

Entendemos que todas as espécies de vidas humanas têm obrigações como doadoras inatas e universais, sob pena de responsabilizarem-se pelo crime de omissão de socorro impróprio, uma das conseqüências desse estudo. 
A impropriedade está no fato de não ser conhecido o agente passível de socorro, e pela inércia da consciência, expressada ou-não, aliada à certeza, que todos nós temos, da existência de muitas vidas necessitadas de socorro biológico.

O nosso ordenamento jurídico foi alicerçado, até os dias atuais, pelo Direito Natural, aquele inerente ao próprio existencialismo da pessoa humana, e na contra-mão desse direito tem a Medicina artificializando-o e mostrando-nos o surgimento de uma nova espécie de direito - o Direito Artificial, cujo estado de morte relativa, nesse estudo inicial, é pressuposto para a sua existência, ou seja, só se fala em Direito Artificial se existir uma potencialidade de vida humana que possa suprir uma vontade ou uma necessidade, advinda da sociedade.

No tocante à expressão potencialidade, segundo uma visão menos ampla de Aristóteles, em analogia ao estudo atual, podemos afirmar que alguns dos "fragmentos humanos" constituem-se de potencialidade fraca para se tornarem pessoas humanas, pois necessitam da intervenção da Medicina moderna.

Já o embrião, o feto e o indivíduo em estado de coma ou EVP, constituemse de potencialidades fortes para se tornarem pessoas humanas, pois dependem apenas do impulso biológico com conseqüente acréscimo da consciência para que se tornem pessoas humanas. Nesse sentido, podemos afirmar que a pessoa humana é a consumação dessas potencialidades.

De modo objetivo, ambas as potencialidades constituem-se de capacidade mediata imprópria de direitos e deveres, com dupla acepção: na primeira, a capacidade que lhe é própria e que será efetivada após a intervenção da Medicina moderna, como exemplo: concepção in vitro; e a segunda o auxílio para resgatar uma capacidade que não lhe é própria, como exemplo: uso das células-tronco na recuperação de uma pessoa humana.

Os juristas, até esse momento, só conheciam o amparo do Direito Natural, e é perfeitamente correta essa linha de raciocínio, desde que sejam considerados somente os atributos naturais inerentes à pessoa humana, cujo ser humano e o impulso biológico relacionam-se e determinam o seu próprio destino.

Contrapondo-se a esse ponto de vista tem a Medicina interferindo e contrariando as leis biológicas da natureza; ao mesmo tempo contribui e caminha para a criação de um direito de incertezas jurídicas, momentâneas, do Direito Artificial.

Devemos agir com atenção, reflexão e coerência, para que um provável colapso jurídico não aconteça diante de situações sem amparo legal. 
A falta de legislação específica e o avanço da Medicina trazemnos comprometimento rumo à responsabilidade, jurídico-biológica, ilimitada e à responsabilidade retroativa.

Dar amparo a essas situações anômalas é a proposta inicial desse estudo, ao se demonstrar que tais situações são fatos atípicos no nosso ordenamento jurídico, sob pena de se provar a infringência do nosso Direito ao Princípio da Reserva Legal, ou seja, "não há crime sem lei anterior que o defina, nem pena sem prévia cominação legal" (art. $5^{\circ}$, XXXIX da Constituição Federal / 1988).

O nosso Código Civil, de 2002, atualizado recentemente, mantém o mesmo caráter personalíssimo, ou seja, a pessoa humana como foco principal das relações jurídicas.

Nos dias atuais é inadmissível entender como capaz, segundo a ordem civil, somente a pessoa humana e sua capacidade imediata própria; pois o estado de morte relativa demonstra possuir capacidade mediata imprópria, ou seja, é a união do Direito Artificial e da morte relativa contribuindo para que outrem modifique a sua condição jurídica anterior; embasada pela nova sistemática da relação jurídica de Direito Artificial, ao oferecer à Humanidade um atributo artificial.

Nesse momento, devemos citar alguns artigos do Código Civil brasileiro, de 2002, para traçarmos algumas considerações; embora saibamos que esse Código nãoampara a situação da nova sistemática proposta.

Entendemos que a Constituição brasileira deve ampliar o sentido de dignidade ao instituir o Princípio da Dignidade da Vida Humana, e provocar a alteração das normas infraconstitucionais.

Nesse sentido, dar-se-ia nova redação ao art. $1^{\circ}$ do Código Civil, de 2002:

Art. $1^{\circ}$. Todas as espécies, de vida humana, são capazes de direitos e deveres na ordem civil.

Esses direitos e deveres teriam duplo sentido: no primeiro, os direitos e deveres, próprios, da pessoa humana vinculados ao Direito Natural; e, no segundo, os da própria condição de vida humana, vinculados ao Direito Artificial, ou seja, o direito de se manter vivo e o dever de contribuir para a preservação da Humanidade.

Já o Capítulo II, do Título I (Das Pessoas Naturais), do Código Civil, de 2002, trata dos direitos da personalidade, como conseqüência do Direito Natural.

Aqui surgem questões conflitantes: o art. 11 foi embasado, salvo nos casos previstos em lei, pelo Direito Natural, como meio essencialmente biológico de vinculação ao poder familiar, via exame de DNA. É a dignidade da pessoa humana, contribuindo 
para o direito de personalidade, que, neste caso, é extremamente coerente. Nesse sentido, cita-se:

Não é a lei que vai conferir ao homem o dom da vida e todas as demais faculdades de que a própria natureza já se incumbiu de dotá-lo. Logo, não é o direito, mas a natureza, que concede as faculdades que lhes são próprias; ao direito compete apenas dar proteção e assegurar o pleno desenvolvimento dessas faculdades, em condições de equilíbrio do indivíduo em relação ao grupo e deste em relação a cada indivíduo. $\mathrm{O}$ direito natural, por ser inerente à condição humana, é imutável como as leis físicas da natureza, ao passo que o direito positivo é circunstancial e se conforma às necessidades e valores momentâneos de cada sociedade. ${ }^{30}$

Parece-nos inadequada essa situação se o artigo fosse embasado pela nova sistemática proposta - a relação jurídica de Direito Artificial, instituída no campo do "querer-ser", na qual prepondera à vontade da "consciência" aliada ao avanço da Medicina, não da Biologia vinculada a uma faculdade que lhe é própria; mesmo porque as doações solidárias, agregadas à recepção, amparada pela gratidão, via intervenção médica; são pré-requisitos para a concepção, e não obra puramente natural.

Neste caso, a vinculação teria caráter essencialmente contratual-altruístico, situação em que se deve prevalecer uma dignidade com maior alcance, a dignidade da vida humana, caso contrário, faz-se prevalecer uma dignidade no sentido unilateral, ou seja, em detrimento de outrem.

$\mathrm{O}$ art. 14 trata da disposição do próprio corpo após a morte, no todo ou em parte, para fins científico e/ou altruístico. Conseqüentemente, tem-se a vontade da consciência prevalecendo sem nenhum amparo legal, quanto às conseqüências futuras. Como exemplo: uma provável hipótese de clonagem humana, a partir de células somáticas extraídas do órgão doado; terá, o clone, como "pai” biológico o mesmo doador do órgão? Ou os "pais" biológicos serão os pais do doador do órgão? Quem sabe?

$\mathrm{O}$ art. 1.597, inciso $\mathrm{V}$ - inseminação artificial heteróloga, cita implicitamente o Direito Artificial amparado pela morte relativa, constituindo-se a nova sistemática proposta. Embora esse método possua situações distintas, devemos citar um exemplo: um casal, em que o homem é infértil e a mulher fértil, recorre a um banco de sêmen com finalidade de concepção, via reprodução assistida (RA).

\footnotetext{
30 Silva apud WELTER, Belmiro Pedro. Temas polêmicos do biodireito moderno. Porto Alegre: Síntese, 1998. p. 237.
} 
Neste caso, não há segurança jurídica quanto às conseqüências de uma futura investigação de paternidade, por parte do concebido; visto que não há amparo legal para o doador do sêmen. Teríamos, no caso, um pai de direito - quem registra, e outro pai de fato - pai biológico, ou seja, uma confusão jurídica com conseqüências desastrosas no âmbito jurídico-familiar.

Não se deve negar a identidade genética entre os envolvidos, "pai” biológico e "filho", fruto da concepção assistida, mas repudiar o anonimato e as conseqüências jurídicas advindas dessa correlação, embasadas por informações puramente biológicas (DNA). Pois, nesse caso, a conseqüência biológica, filho gerado, é apenas o fruto da expressão do resultado advindo da solidariedade e gratidão, ou seja, um "contrato altruístico" amparado por "sentimentos bilaterais análogos", fato atípico não-disciplinado no nosso ordenamento jurídico.

Nesse sentido, as expressões "pai" e "filho", por estarem envolvidos com sentimentos maiores, devem ser substituídas por "genitor biológico solidário" e "fruto da solidariedade", respectivamente.

Hoje é inadmissível que prepondere somente o fator biológico como fonte de prova, para dirimir questões que envolvam o poder familiar, parentesco, alimentos, sucessões, etc., mesmo porque é contraditório o entendimento da norma jurídica que adota a pessoa humana como objeto central, na qual prepondera a expressão da consciência, e ao mesmo tempo nega-se à própria consciência o direito de dirimir fatos sensivelmente relevantes.

O nosso ordenamento jurídico deve tratar a vida com propósito em si mesma, deve adiantar-se no sentido de se resgatar, diante das novas situações, os verdadeiros sentidos conceituais de vida, morte e dignidade.

\section{Alguns questionamentos envolvidos com o Direito Penal}

As dúvidas sobre as conseqüências que envolvem a interferência sobre uma vida biológica humana, desprovida de consciência, não interferem no foco desse estudo; apenas induzem o pensamento sobre situações, no mínimo, curiosas.

Não podemos negar a extrema importância, para o Direito Penal, em definir o tipo penal adequado às novas relações de vida.

Para fortalecer os questionamentos a seguir, convém destacar os ensinamentos de Aristóteles sobre a questão potencialidade, em analogia a esse estudo. 
Podemos afirmar que a vida humana se compõe de três situações básicas: a potencialidade fraca, a potencialidade forte e a pessoa humana; que, segundo interpretação dessa linha de estudo, passamos a entendê-la como a consumação dessas potencialidades, pois entendemos que a pessoa humana é o objeto final da vida biológica humana consumada.

Nessa linha de raciocínio, é inconcebível imaginar uma tipificação penal, embasada em potencialidades, sejam iminentes ou-não, uterina ou extra-uterina; e que esse estudo a entende como capacidade mediata imprópria, pois pressupõe algo que poderá ser, mas ainda não o é.

Tipificá-las, nessas condições, é admitir que o ser humano masculino, também pode praticar o auto-aborto (art. 124 do CP), ao expelir o sêmen ejaculado, via masturbação, pois se trata do descarte de uma vida humana - ser humano, com potencialidade fraca; ou seria o caso de homicídio? (art. 121 do CP), pois há a morte de uma vida humana - o sêmen.

No caso das células-tronco, seria admitir o crime de aborto extra-uterino, cuja responsabilidade seria imputada aos pais biológicos em co-autoria (art.124 do CP), ou imputar-se-ia a um terceiro com o duplo consentimento dos pais. (art. 126 do CP)

Mesmo que tais situações sejam suscitadas, esbarrariam na outra face do fato atípico, pois, para o Código Penal vigente, a prática do aborto pressupõe uma gestante, ou seja, uma pessoa humana, do sexo feminino, em estado de gravidez, ao carregar no seu útero um novo ser humano.

Nesse mesmo sentido é o posicionamento do Código Penal de 1940, vigente: art. 124 - ... "em si mesma"; art. 125 - ... "da gestante"; art. 126 - ... "da gestante".

Seria o caso de homicídio? (art. 121 do CP), a extração de células-tronco de um embrião extra-uterino, pois resultaria a morte dessa vida humana com "potencialidade forte".

Tratar-se-ia de lesão corporal seguida de morte? (art. 129, § $3^{\circ}$ do CP), pois esse embrião deixaria de exercer a função de procriação, seguindo-se de morte.

Poder-se-ia tipificar como abandono de incapaz? (art. 133 do CP), pois, ainda, não the foi acrescido o valor consciência.

Seria o caso de cárcere privado? (art. 148, $\S 1^{\circ}$, inciso I), o ato de criopreservar, pois se está diante do aprisionamento de uma vida humana.

Contudo, alterando-se essa linha de raciocínio, poder-se-ia desconsiderar todos esses questionamentos ao admitir um estado de necessidade generalizado? (art. 24 do $\mathrm{CP})$, pois a "vida humana fragmentada", na maioria dos casos, relaciona-se, intimamente, 
com a vida humana potencialmente consumada - a pessoa humana, com o intuito de preservação.

Obviamente, não se precisa de grande esforço para apresentar situações, envolvidas com as "novas relações de vida", que se encontram absolutamente alheias ao Direito.

Nesse sentido, conclui-se que qualquer debate que possa existir sobre a tipificação de um crime, envolvendo vida humana, desprovida de consciência, não passará de retórica inconsistente, pois o Direito atual, infelizmente, só conhece e ampara uma de suas espécies - a pessoa humana.

Aplica-se a nova sistemática no sentido de se demonstrar que quando houver um conflito de bens humanos a serem protegidos, ou seja, pessoa humana versus "fragmentos humanos", a solução deverá amparar-se no raciocínio lógico de que, diante de situações patológicas especiais, somente a vida humana poderá salvar-se a si própria; nesse caso a decisão observará qual vida humana terá o direito à vida e qual dará o direito à vida - Princípio da Horizontalidade Hierárquica da Efetividade Vital.

"Igualar todas as espécies de vidas humanas à pessoa humana é desprezar a essência da vida, e enxergar a vida humana segundo uma potencialidade".

10. Primeiros reflexos relacionados à legislação vigente

Não basta observar as mudanças, mas adequá-las ao mundo jurídico, com o fim de se evitar maiores danos.

Nesse sentido, suscitamos alguns reflexos relacionando-os à legislação vigente:

- A necessidade da desbiologização do Direito.

- Surgimento do novo conceito, jurídico, de morte - morte relativa, que ao se unir a artificialização do direito natural - direito artificial, cria-se uma nova sistemática interpretativa para o Direito - a relação jurídica de direito artificial.

- Surgimento de uma nova era: o Período Cíclico, inerente à sistemática da relação jurídica de direito artificial.

- Modificação do Princípio Constitucional da Dignidade da Pessoa Humana, para Princípio da Dignidade da Vida Humana.

- A Medicina amplia o sentido de dignidade, ao fornecer à Humanidade o atributo artificial. 
- Surgimento do sistema contratual-altruístico, com força de coisa julgada.

- Inserção da solidariedade como fonte legítima de prova.

- Fim do anonimato sobre questões que envolvam a vida humana.

- Doadores de sêmen ou óvulos, em algumas situações, não deverão ser considerados ou responsabilizados "pais".

- Inserção da expressão genitor biológico solidário na certidão de nascimento, para definir o responsável biológico.

- Obrigatoriedade de doação dos "fragmentos humanos", como exemplos: órgãos, sangue, medula óssea, tecidos, córneas, etc.

- Surgimento dos crimes: omissão de socorro impróprio e homicídio relativo.

- Crimes ambientais devem ser interpretados como crimes contra a Humanidade - crime de genocídio iminente.

- Direito de optar pela vida ou morte.

- O aborto e a eutanásia, em algumas situações, não devem ser entendidos, ou considerados, como crimes.

- Interrupção de prazos processuais.

- Etc...

\section{Conclusão}

ACiência, no sentido genérico, é una; e, quando suas espécies identificaremse sobre um mesmo conteúdo, deverão transmiti-lo numa mesma sintonia racional, para que a sociedade possa assimilar conhecimentos úteis, e exprimir com segurança uma opinião soberana. É o que não ocorre com o Direito, a Medicina e a Religião, quando discutem sobre o gênero Vida Humana.

Importante observar que as expressões: ser humano e vida humana estão sendo vinculadas, somente, à pessoa humana; um equívoco que precisa ser esclarecido.

"Ser 'ser humano' não é atributo exclusivo da pessoa humana", e deve ser entendido como tudo aquilo que se constitui de matéria humana; portanto, os "fragmentos humanos" (órgãos, embriões, células-tronco, sêmen, óvulo, etc.), são seres humanos.

Já a vida humana deve ser entendida como um gênero que detém três espécies distintas: a pessoa humana, o indivíduo humano e os "fragmentos humanos". 
Para o Direito, há uma explícita vinculação, no sentido de vida humana, com a capacidade e personalidade, jurídicas, de expressar uma consciência.

Para a Medicina - Ciência da Vida, a vida humana tem acepções mais amplas. E é entendida como todo o "ser" composto de matéria orgânica humana, guiada pelo impulso biológico. Alguns exemplos desse impulso biológico: a "corrida" dos espermatozóides ao encontro do óvulo; a divisão celular; o germinar das sementes; o florescer das plantas; etc.

Para a Religião, o sentido da vida humana está embasado por algo transcendental, que alimenta a materialidade humana, ou seja, a vida é uma energia, alma, espírito, ou uma consciência emanada de um bem supremo - Deus, cuja explicação encontra-se respaldada pela dogmática religiosa e sua incontestável "verdade de fé".

Há de se ponderar que exista toda essa discussão, pois essas instituições, ao longo do tempo, perderam, ou nunca tiveram, a capacidade de interpretar uma mesma linguagem universal - a "linguagem vital", própria de todas as espécies de vidas existentes no nosso planeta; que se manifestam exclusivamente pelo "impulso biológico", e que entendemos ser a concretização da "linguagem vital" manifestada pela capacidade que todos os seres possuem de guiar-se numa finalidade predeterminada - Teleologia Biológica.

O ponto crucial que deverá ser respeitado por essas instituições é a observação de que o organismo humano possui três aspectos distintos: o desenvolvimento amparado somente pelo impulso biológico (campo da Medicina); o acréscimo do valor consciência a esse organismo, como pré-requisito ao mundo jurídico (campo do Direito); e a lapidação desse conjunto quanto aos aspectos morais e éticos, diante de um bem supremo - Deus, (campo da Religião).

Diante do exposto, fica explícita a existência de duas espécies distintas de vidas, agregadas ao ser humano: o impulso biológico e a consciência humana, que, em tese, jamais deveriam confundir-se.

O desequilíbrio dessas opiniões é o entendimento de que a pessoa humana é a única e legítima espécie detentora do valor vida humana; cujo atributo de ser "ser humano" é atribuído somente a ela; entendimento que se perpetua até os dias de hoje.

Contudo, a Medicina - Ciência da Vida -, mesmo que inconscientemente, provou-nos que esse entendimento desatualizou-se, em decorrência da sua evolução, que se fez necessária diante da demanda social.

Nesse contexto, procuramos demonstrar que os conceitos de morte, vida e dignidade careciam de novas adaptações diante da sociedade, apresentando-lhes soluções 
jurídicas mais adequadas a essas novas realidades de relações jurídicas - relações jurídicas de Direito Artificial.

Num sentido genérico, procuramos demonstrar que a morte absoluta, tecnicamente, não mais existe e, analogicamente, transferimos essa hipótese para os dias atuais, cuja Medicina é o veículo.

Demonstramos que a vida humana, ao contrário do entendimento clássico, é um gênero que detém três espécies: a pessoa humana, o indivíduo humano e os fragmentos humanos; e que foi inserida numa estrutura biodiversa como membro mais frágil.

A morte relativa e o Direito Artificial, ao se unirem, criaram uma nova sistemática de raciocínio interpretativo para o Direito - a relação jurídica de Direito Artificial, ao trazer consigo o caráter revolucionário de questionamentos quanto ao verdadeiro bem a ser tutelado, ou seja, a Biologia, a consciência ou ambos.

Exatamente a partir desse ponto é que a Ciência do Direito se perdeu, cujas tentativas equivocadas de interpretações extensivas, usadas como método de atualizações doutrinárias, trouxeram as lacunas e as omissões diante de um provável quadro de injustiça, insegurança e indignidade.

Evidentemente, ambos os bens são tutelados, contudo devem existir prioridades dependentes da relação jurídica envolvida em cada caso.

Nas relações jurídicas, amparadas pelo Direito Natural - campo do ser; o homem, o impulso biológico e os sentimentos próprios, relacionados ao atributo natural; subordinam-se à disciplina do sistema imperativo biológico. Como exemplo, método natural de concepção.

Nas relações jurídicas, propriamente ditas, campo do dever ser; as pessoas, amparadas por normas jurídico-sociais, ao definir uma disciplina comportamental; relacionam-se ao compromisso de obediência à lei.

Essas novas modalidades de relações jurídicas, que apresentamos, amparamse pelo Direito Artificial - campo do querer-ser, em que o homem, a Medicina, o estado de morte relativa, a consciência bilateral e os sentimentos análogos, relacionados ao atributo artificial; subordinam-se ao sistema contratual-altruístico.

Sistema que não há partes, somente troca de sentimentos entre solidariedade e gratidão, que deverão ser definidos expressa e formalmente com força de coisa julgada, após efetiva concretização.

Aplicar essas novas relações jurídicas ao Princípio da Dignidade da Pessoa Humana, é aplicar a responsabilidade ilimitada, a retroatividade e a desigualdade com 
prejuízo unilateral; pois a essência da dignidade é a universalidade, que se deve aplicar a todos com coerência, respeito e imparcialidade.

Responsabilizar alguém, biologicamente, por situações atípicas, nãodisciplinadas no ordenamento jurídico, é praticar a insegurança jurídica, a indignidade e a injustiça social.

Quanto mais nos aproximamos dessa nova sistemática, mais enfocamos o paradoxo dos verdadeiros sentidos jurídicos para a vida, morte e dignidade, cuja consciência é a verdadeira razão para a sustentação da existência do valor vida humana.

O que se ouviu até hoje é que os fatos andam à frente do Direito. A vida não pode ser objeto de defasagem legislativa; mas amparada, concomitantemente, à evolução social.

Nesse sentido é que apresentamos esse estudo, pois possui um caráter dinâmico, ao atribuir o direito de escolha à própria integridade biológica humana.

Devemos ter consciência e sensibilidade, em observar que caminhamos para um complexo social, em que prepondera o "estelionato institucionalizado"; e que o único caminho para repudiá-lo, é a conscientização imperiosa sobre a obrigação de caminhar nessa nova era - o período cíclico, que se caracteriza pela revolução dos valores; em que a vida deve ser compartilhada e envolvida por sentimentos maiores, como a esperança, a solidariedade, a gratidão, a preservação, e, no topo dessa hierarquia sentimental, o respeito; todos amparados por um princípio ainda maior, ou seja, o Princípio da Dignidade da Vida Humana.

“Quanto ao sentimento maior, o amor, este sim inatingível quanto ao alcance social, pois é utópico imaginar uma sociedade absolutamente imperfeita conceber a plenitude da perfeição".

Essa nova concepção principiológica, ao tutelar a preservação da vida humana, transcenderá à garantia de sobrevivência de uma espécie em favor de outra, ou seja, quando houver um conflito que envolva bens humanos, dever-se-á permitir a tutela de um em detrimento de outro, segundo o direcionamento do consciente justo-dignoaltruísta, que assim o determinar.

A vida não pode, sob quaisquer pretextos, ser alvo do antagonismo legislativo, pois se existem leis dotadas de hierarquia, existem-nas em função da própria Vida, que também é dotada de hierarquia suprema; e as criaturas que representam o Poder Legislativo, no âmbito mundial, que ainda insistem em brincar de "deuses", não podem e nem devem discipliná-la, ao exigi-la que suporte os impactos jurídicos, sociais 
e ambientais, diante de uma involução declarada; apenas ampará-la segundo uma visão humano-altruísta, caso contrário está-se diante de uma Inconstitucionalidade Vital.

Tal insistência provocará a fúria do seu silencio eloqüente, cujas respostas serão sempre exemplos de devastação da vida humana, em todos os seus aspectos, e talvez a sua própria extinção. Mesmo assim o gênero Vida se perpetuaria.

Sentimo-nos realizados, com todas as limitações de seres humanos que somos, em poder oferecer à Humanidade subsídios iniciais para a construção de uma base sólida para um mundo justo, inicialmente exclusivo para o campo do Biodireito; e que poderá contribuir para que a sociedade seja merecedora de Justiça e Dignidade, que lhes serão concedidas, não-só pelo Direito, mas pela Supremacia Vital.

Que seja esse estudo o primeiro passo para que a sociedade exija, dos seus representantes, modificação de lei existente ou elaboração de lei específica, para que não se pratiquem, no futuro próximo, injustiças irreparáveis diante do verdadeiro sentido de Dignidade.

Esperamos que esse estudo crie uma espécie de jus-artificialismo, ao aproximar cientistas, juristas e filósofos que o consagrem como fonte de estudo científicoracional, inerente aos princípios de proteção da Dignidade da Vida Humana.

Criamos, para essa nova era, um pensamento que reflete a essência do novo princípio constitucional - Princípio da Dignidade da Vida Humana, proposto nesse estudo.

“A Consciência é a arte; a Biologia, o meio de expressão; e o Direito, o amparo da dignidade".

Bauru, São Paulo, agosto de 2007.

\section{Referências}

A BASE cromossômica da hereditariedade. Disponível em: <http://www.virtual.epm.br/ cursos/ genética/htm/gametas>. Acesso em: 26 Jul 2005.

ALARCÓN, Pietro de Jesús Lora. Patrimônio Genético Humano e a sua proteção na Constituição Federal de 1988. São Paulo: Método, 2004.

ALMEIDA, Sabrina Chagas; TEIXEIRA, José Sérgio Boscayano. Conceito médico-legal de morte e aspectos médico-legais. Disponível em: <http://www.neofito.com.br/ artigos/ art01/jurid27.htm>. Acesso em: 07 mar 2005. 
A origem do Biodireito universal Morte relativa: um Direito Artificial, uma nova sistemática interpretativa para o Direito

ANTONIAZZI, Alberto. A morte na abordagem filosófica. In: D’ASSUMPÇÃO, Evaldo Alves; D’ASSUMPÇÃO, Gislaine Maria; BESSA, Halley Alves, (Orgs). Morte e suicídio: uma abordagem multidisciplinar. Petrópolis: Vozes, 1984.

ARAUJO, Luiz Alberto David; NUNES JUNIOR, Vidal Serrano. Curso de Direito Constitucional. 4. ed. São Paulo: Saraiva, 2001.

BARBOZA, Heloísa Helena. Novos temas de Biodireito e Bioética. Rio de Janeiro: Renovar, 2003. BOBBIO, Norberto. A era dos direitos. Tradução de Carlos Nelson Coutinho. 9. ed. Rio de Janeiro: Campus, 1992.

BUENO, Francisco da Silveira. Minididicionário da língua portuguesa. São Paulo: Atual, 2000.

CHAMOUN, Ebert. Instituições de Direito Romano. 5. ed. São Paulo / Rio de Janeiro: Forense, 1968.

CHAVES, Antônio. Direito à vida e ao próprio corpo: intersexualidade, transexualidade, transplante. São Paulo: RT, 1994.

CLONAGEM. Disponível em: <www.escolavesper.com.br/clongem>. Acesso em: 31 jul. 2005.

CLONAGEM. Disponível em: <http://www.suapesquisa.com/clonagem>. Acesso em: 31 jul. 2005. D’ASSUMPÇÃO, Evaldo Alves. Aspectos médicos da morte. In: D’ASSUMPÇÃO, EvaldoAlves; D’ASSUMPÇÃO, Gislaine Maria; BESSA, Halley Alves (Orgs). Morte e suicídio: uma abordagem multidisciplinar. Petrópolis: Vozes, 1984.

DINIZ, Maria Helena. Norma constitucional e seus efeitos. 3. ed. São Paulo: Saraiva, 1997.

DINIZ, Maria Helena. O estado atual do biodireito. 2.ed. São Paulo: Saraiva, 2002.

DINIZ, Maria Helena; LISBOA, Roberto Senise. (Coords.). O direito civil no século XXI. São Paulo: Saraiva, 2003.

FERREIRA, Aline Teixeira et al. Vida: o primeiro direito da cidadania. Goiânia: Bandeirante, 2005.

GARCIA, Edinês Maria Sormani. O princípio da dignidade da pessoa humana e a leitura do Novo Código Civil em relação à família. In: HIRONAKA, Giselda Maria Fernandes Novaes (Org). Novo Código Civil. Interfaces no ordenamento jurídico brasileiro. Belo Horizonte: Del Rey, 2004.

GERÊNCIA. Coma e estado vegetativo. Disponível em: <http://www.gerenciade projetos.com/ coma>. Acesso em: 26 Jul 2005. 
JACINTO, E. Entenda a clonagem, suas promessas e limitações. Disponível em: <http://www. escolavesper.com.br/clonagem.htm>. Acesso em: 31 jul. 2005.

MADEIRA, Pedro. Crítica. Disponível em: <http://www.criticanarede. com/aborto $1 \mathrm{htm}>$. Acesso em: 30 mar 2007.

NADER, Paulo. Introdução ao estudo do Direito. 22. ed. Rio de Janeiro: Forense, 2002.

OLIVEIRA, Elisa Pinto de. Tradutora Pública e Intérprete Comercial. Mestre em Letras, pelo Programa de Estudos Lingüísticos e Literários em Inglês da F.F.L.C.H. (USP). Tradução em: 25 Jan 2007.

OTERO, Paulo Manuel Cunha da Costa. Personalidade e identidade pessoal e genética do ser humano: um perfil constitucional da bioética. Coimbra: Almedina, 1999. 104 p.

SACCONI, Luiz Antônio. Minidicionário Sacconi da língua portuguesa. São Paulo: Atual, 1998.

SÉGUIER, Jaime de. Dicionário prático ilustrado. Porto: Lello \& Irmão, 1961.

SCHWARTZ, Gary. Memória no transplante de figado. Fantástico. Disponível em: $<$ http://www. fantastico.globo.com/Portal/jornalismo>. Acesso em: 12 Jun 2005.

SEGATTO, Cristina. Artigo raro na praça. Disponível em: <www.epoca.com.br>. ed.220, 05 ago. 2002. Acesso em: 26 jul. 2005.

SILVA, Áurea Starling Albuquerque Penido. Aspecto social da morte. In: D’ASSUMPÇÃO, Evaldo Alves; D’ASSUMPÇÃO, Gislaine Maria; BESSA, Halley Alves, (orgs). Morte e suicídio: uma abordagem multidisciplinar. Petrópolis: Vozes, 1984.

TOMASEVICIUS FILHO, Eduardo. Direito civil entre a vida e a morte. Revista da Faculdade de Direito da Universidade de São Paulo, São Paulo, v. 100, p. 433-471, jan./dez. 2005.

WELTER, Belmiro Pedro. Temas polêmicos do Biodireito moderno. Porto Alegre: Síntese, 1998.

ZATZ, Mayana. Células-tronco. Disponível em: <http://www.drauziovarella.com.br/entrevistas/ www.genoma.ib.usp.br>. Acesso em: 31 jul 2005. 